\title{
Heterogeneity of stage IIIA non-small cell lung cancer-different tumours, different nodal status, different treatment, different prognosis: a narrative review
}

\author{
Dominik V. Flury $^{1 \wedge}$, Fabrizio Minervini ${ }^{2}$, Gregor J. Kocher ${ }^{1}$ \\ ${ }^{1}$ Department of Thoracic Surgery, Inselspital, Bern University Hospital, University of Bern, Bern, Switzerland; ${ }^{2}$ Department of Thoracic Surgery, \\ Kantonsspital Luzern, Lucerne, Switzerland \\ Contributions: (I) Conception and design: All authors; (II) Administrative support: All authors; (III) Provision of study materials or patients: All \\ authors; (IV) Collection and assembly of data: All authors; (V) Data analysis and interpretation: All authors; (VI) Manuscript writing: All authors; (VII) \\ Final approval of manuscript: All authors. \\ Correspondence to: Gregor J. Kocher. Division of General Thoracic Surgery, Department of Thoracic Surgery, Inselspital, Bern University Hospital, \\ University of Bern, 3010 Bern, Switzerland. Email: gregor.kocher@insel.ch.
}

\begin{abstract}
Stage IIIA non-small cell lung cancer (NSCLC) consists of a heterogeneous group of disease, ranging from small T1a tumours with ipsilateral mediastinal lymph node involvement over T3 tumours with chest wall invasion, up to T4 tumours with mediastinal invasion with or without positive hilar lymph nodes. Based on this heterogeneity, treatment approaches as well as prognosis are very dependent on specific subgroups. Therapy recommendations should be based on multidisciplinary case discussions in high volume centres including medical and radiation oncologists, pneumologists and experienced thoracic surgeons specialized in thoracic cancer surgery. Recommendations may differ from standards in highly selected cases. Therefore, independent of age, in medically fit (operable) patients with resectable stage IIIA tumours, an aggressive approach in a curative setting is key to obtain good overall survival rates. Moreover, maintaining quality of life is essential. In this narrative review, the different aspects of all the subgroups of stage IIIA NSCLC and their heterogeneity as well as the variety of treatment modalities, their combined treatment approaches and survival rates are discussed. Again, the reported 5-year survival rates, ranging from $5 \%$ in patients with bulky N2 disease, up to $50 \%$ for patients with superior sulcus tumours with hilar lymph node disease, reflect the heterogeneity of stage IIIA NSCLC.
\end{abstract}

Keywords: Non-small cell lung cancer (NSCLC); stage IIIA; multimodal therapy

Received: 04 May 2020; Accepted: 24 September 2020; Published: 25 May 2022.

doi: $10.21037 /$ ccts-20-97

View this article at: http://dx.doi.org/10.21037/ccts-20-97

\section{Introduction}

Lung cancer is one of the most common cancers (1) and by far the leading cause of cancer deaths worldwide with a 5 -year survival rate of approximately $19 \%$, including both non-small cell lung cancer (NSCLC) and small cell lung cancer (SCLC) (2). According to the WHO classification, lung cancer is divided into two major types based on its molecular characterization, therapy and prognosis, comprising about $95 \%$ of all lung cancers. These two groups are NSCLC and SCLC. The remaining $5 \%$ are other cell types $(2,3)$.

\section{Stage IIIA TNM classification, pre-treatment evaluation and prognosis}

To stage lung cancer, the current eighth edition of the

\footnotetext{
$\wedge$ ORCID: 0000-0002-5829-4692.
} 
Table 1 Lung cancer stage grouping (eighth edition) (4): TNM-constellation for stage IIIA is highlighted

\begin{tabular}{|c|c|c|c|c|}
\hline $\mathrm{T}$ and $\mathrm{M}$ & No & N1 & N2 & N3 \\
\hline T1 & & & IIIA & \\
\hline T2 & & & IIIA & \\
\hline T3 & & IIIA & & \\
\hline T4 & IIIA & IIIA & & \\
\hline M1 & & & & \\
\hline
\end{tabular}

TNM, tumor, node, metastasis.

Tumor, Node, Metastasis (TNM) classification is used (4). The TNM staging system combines patients with differences in extent and localization of the primary tumour with patients with ipsilateral peribronchial, hilar or mediastinal lymph node metastasis to create the highly heterogeneous group of stage IIIA NSCLC (Table 1). Reported 5 -year overall survival rates are $36 \%$ for clinical stage IIIA and $41 \%$ for pathologic stage IIIA disease (4-6).

Adequate staging using contrast-enhanced CT scan of the chest and upper abdomen followed by a positron emission tomography (PET) scan is indicated in order to rule out extrathoracic, extracranial metastasis and assess a potential mediastinal lymph node involvement. Evaluation of possible existence of brain metastasis by contrastenhanced brain magnetic resonance imaging (MRI) is also recommended for patients with stage IIIA NSCLC, especially in those who could potentially receive treatment in a curative intent (7-12). In patients with sulcus superior tumours a thoracic MRI for evaluation of the thoracic inlet with vascular, brachial plexus or vertebral invasion is recommended. In these T3-4 sulcus superior tumours, exclusion of mediastinal lymph node involvement or metastatic disease is particularly important, because these tumours would then be classified as stage IIIB or IV, where resection is contraindicated (13).

Assessment of the nodal status is an exceedingly important component in pre-treatment evaluation because it will highly affect the individual treatment plan. Based upon enlargement in the CT scan or FDG-avidity in the PET scan, hilar and especially mediastinal node involvement should be pathologically confirmed (7-12). This can be done using minimally invasive endoscopic techniques such as endoscopic ultrasound fine needle aspiration (EUS-FNA) and endobronchial ultrasound with transbronchial needle aspiration (EBUS-TBNA) (14-19).
Consequently, performing a mediastinoscopy is appropriate and recommended by many authors for patients with T2 to T3 lesions even if the CT scan or/and the PET scan do not suggest a mediastinal lymphadenopathy and despite a previous negative EBUS-TBNA $(7,9,12,20,21)$. However, in already assumed $\mathrm{cN} 2$ disease and if complete resection is anticipated, the necessity of an additional invasive pathological confirmation is questioned by some authors and remains controversial (22).

Pathologic confirmation of diagnosis and complete staging are essential in treatment evaluation of stage IIIA disease. After the clinical evaluation and when tumour stage is determined, a multidisciplinary evaluation should be done to assign the patient to one of the treatment pathways according to TNM stage, location of the tumour and cardiopulmonary fitness as well as patient performance status regardless of age (7-12).

Based on the heterogeneity of stage IIIA and especially regarding mediastinal nodal involvement, many aspects of therapy have not clearly been defined and recommendations overall remain controversial.

Significance of available data is often limited. For example, considering the redefinition of stage IIIA disease over time, the included heterogeneous patient populations or missing randomization in available trials and the limited follow-up duration together with major changes in staging and therapy modalities, it is difficult to generally apply these results in clear treatment recommendations.

The histopathologic cell type together with the TNM classification and the disease stage have the biggest impact on prognosis. As Asamura et al. reported, nodal status is considered one of the most reliable prognostic indicators in patients with lung cancer. The number of involved nodes as well as their distribution have a significant impact on prognosis. The difference between separate nodal categories also significantly differs between the clinical $(\mathrm{cN})$ and the pathological $(\mathrm{pN}) \mathrm{N}$ status. For the subgroups of $\mathrm{pN}$ status, single-station $\mathrm{N} 2$ metastasis without $\mathrm{N} 1$ involvement or skip N2 (N2a1) had numerically a better prognosis than multiple-station N1 involvement (N1b), but results were not statistically significant. N1b status and single station N2 with $\mathrm{N} 1$ involvement (N2a2) had overlapping survival curves. The 5 -year survival rates according to the $\mathrm{cN}$ and $\mathrm{pN}$ status were $60 \%$ and $75 \%$ for N0, $37 \%$ and $49 \%$ for N1, $23 \%$ and $36 \%$ for N2, and $9 \%$ and $20 \%$ for N3 nodal disease, respectively (23-26). For complete resected N1-2 disease, reported 5-year survival rates were as follows: $59 \%$ in N1a, $50 \%$ in N1b, $54 \%$ in N2a1, 43\% in N2a2 and 38\% in N2b involvement (23). 
Table 2 Stage IIIA NSCLC_-treatment recommendations and prognosis for resectable tumours and operable patients

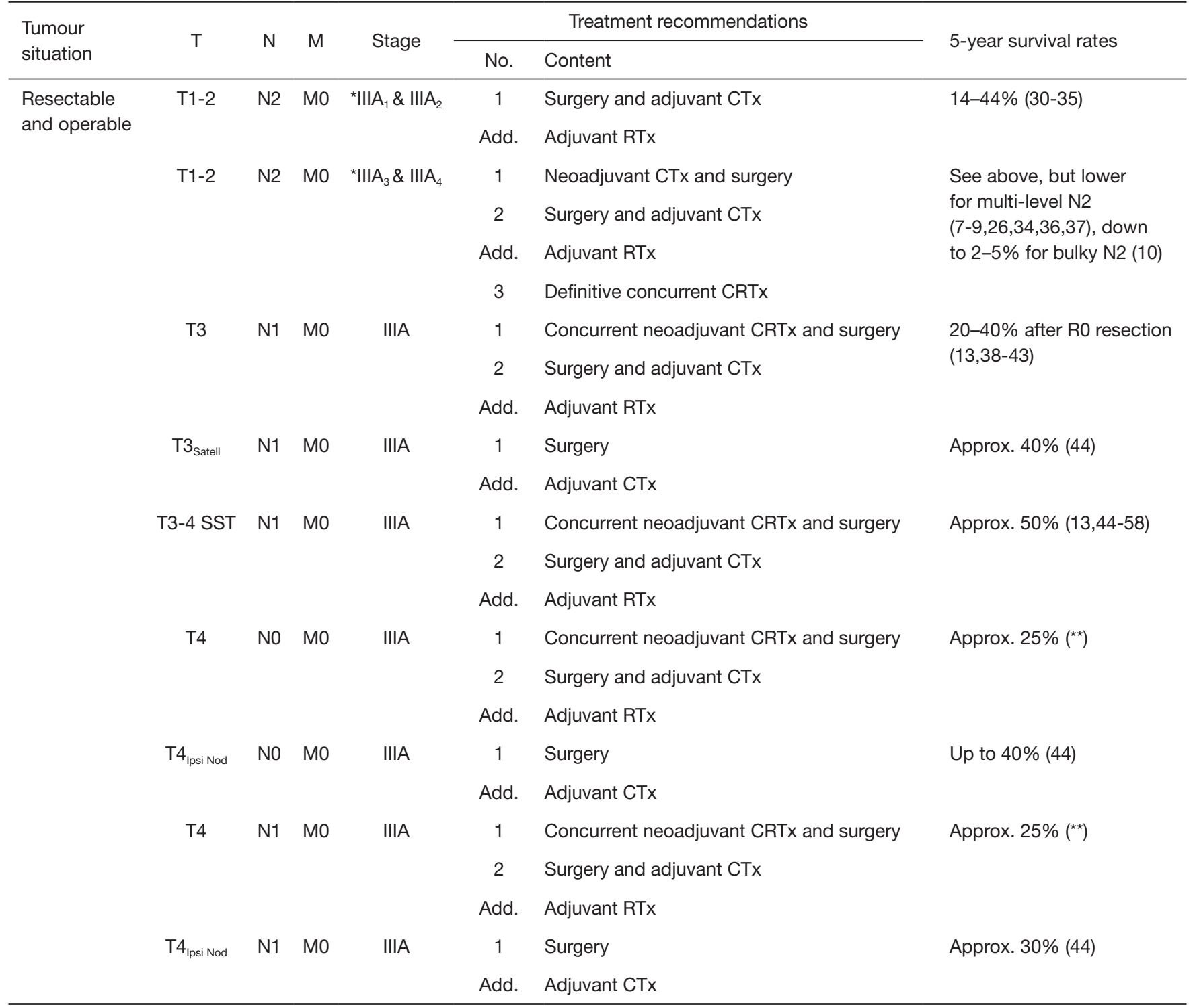

*, Robinson classification; **, T4 tumours with invasion ( $\left.\mathrm{T}_{\text {Inv }}\right)$ of: mediastinum (53,59-62), diaphragm (63-68), heart and great vessels (60), left atrium and pulmonary veins (13,69-84), SVC (13,53,69,78,83-96), inferior vena cava (83), pulmonary artery $(53,70,84,97,98)$, aorta $(13,69,81,84,88,99-104)$, recurrent laryngeal nerve (70), carina and trachea $(13,38,53,70,84,105-110)$, esophagus (53,70), vertebral bodies and spine (13,38,57,58,111-119). NSCLC, non-small cell lung cancer; CTx, chemotherapy; RTx, radiotherapy; CRTx, chemoradiotherapy; add., additionally; SST, sulcus superior tumours; SVC, superior vena cava.

Another important clinical parameter is the performance status (26-29). There is no standard approach in patients with poor performance status who are high risk candidates for a multimodality treatment and individual therapy recommendations should be formed by a multidisciplinary board.

Whenever feasible, patients with stage IIIA NSCLC are treated with a curative intent using a combined approach of two or more of the following modalities: surgery, chemotherapy, radiotherapy and in case of unresectable stage IIIA disease, added immunotherapy may be beneficial in highly selected cases (7-12). We present the following article in accordance with the Narrative Review reporting checklist (available at https://ccts.amegroups.com/article/ view/10.21037/ccts-20-97/rc).

Therapy recommendations and prognosis are 
Table 3 Stage IIIA NSCLC—-treatment recommendations for unresectable tumours and/or inoperable patients

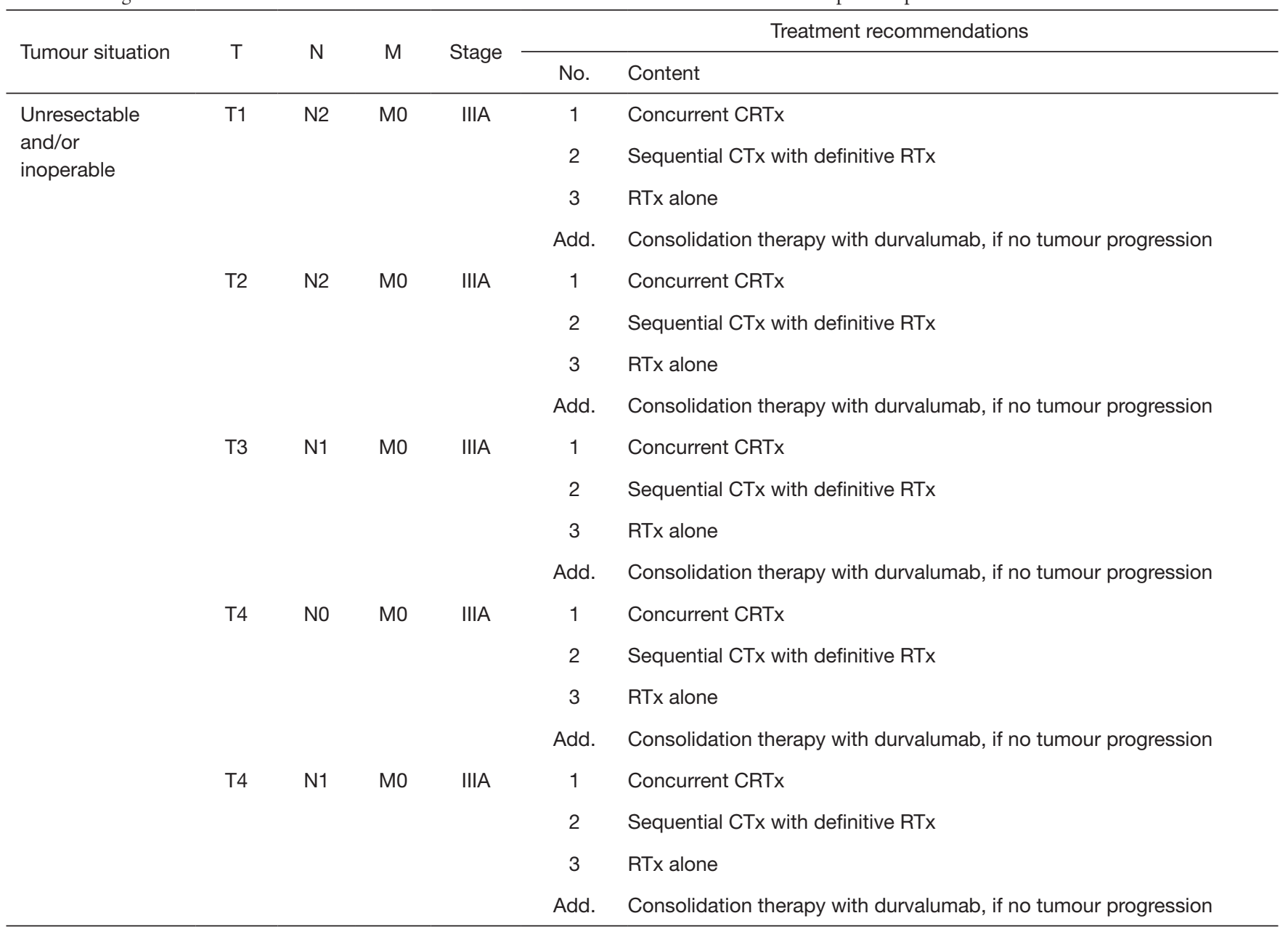

NSCLC, non-small cell lung cancer; CTx, chemotherapy; RTx, radiotherapy; CRTx, chemoradiotherapy; add., additionally.

summarized in Tables 2,3.

\section{Methods}

To determine the current clinical evidence of evaluation and management of NSCLC, we searched two electronic databases (PubMed and the Cochrane Library) for articles from 1988 to March 2020 as well as the most recent guidelines in English and German language. Date of last search was March 14, 2020.

The rarity of advanced T-stages and the heterogeneity of these subgroups making randomised controlled trials nearly impossible. Therefore, regarding the limited data published, we also included multiple case series to identify survival rates and outcome of specific heterogenous subgroups of stage IIIA disease.

We checked cross-references and searched references from all the mentioned guidelines, review articles and published series. The articles included were assessed for eligibility by the three authors.

\section{Therapeutic approaches}

After complete staging and prior to definitive therapy it is strongly recommended to determine the resectability of the tumour, the extent of pulmonary resection and the operability of the patient according to pre- and postoperative pulmonary function and concurrent comorbidities in a multidisciplinary tumour board $(7-11,13,120,121)$. If this board deems that even after 
induction therapy a complete resection (R0) of the tumour is not possible, surgery should not be attempted and concurrent chemoradiotherapy offers the most beneficial treatment option for this subgroup of stage IIIA disease (7-9,122-128).

In patients with stage I and II disease, radical and anatomical surgical resection provides the best longterm survival. For stage IIIA disease and medically operable patients with resectable tumours, surgery may be appropriate for carefully selected cases in a combinedmodality treatment approach, even in locally advanced tumours with chest wall involvement, in sulcus superior tumours or T4 with mediastinal organ invasion $(7-11,13)$.

The extent of anatomical pulmonary resection depends on cardiopulmonary reserve and extent of disease. In T1a and T1b tumours before staged as IIIA $_{1}$ and IIIA $_{2}$, sublobar resection with either segmentectomy or even wedge resection (patients with poor pulmonary reserve or major comorbidities with contraindication for lobectomy) is appropriate $(7,129-134)$. For tumours $>2 \mathrm{~cm}$ (T1c-T4) lobectomy or pneumonectomy should be considered if allowed by cardiopulmonary function and medical comorbidities, and whenever possible, lung-sparing anatomical resection such as sleeve lobectomy should be performed, rather than pneumonectomy $(7,9,129)$.

Besides pulmonary resection hilar and mediastinal lymphadenectomy plays a key component in lung cancer surgery $(7-11,13)$. It is controversial whether complete mediastinal lymph node dissection (MLND) or mediastinal lymph node sampling (MLNS) is the preferred approach. Current evidence suggests that MLND adds a small to moderate improvement in survival compared to MLNS $(10,135-137)$. In case of MLNS, a minimum of three hilar and three mediastinal stations should be sampled and if there is $\mathrm{N} 2$ nodal involvement in stage $\mathrm{IIIA}_{3}$ or in selected cases of $\mathrm{IIIA}_{4}$ (e.g., multi-level), radical MLND is clearly indicated to achieve a complete resection $(4,7)$.

In all patients with stage IIIA disease pre- or postoperative chemotherapy and/or radiation therapy should be considered $(7-11,13)$. Radiotherapy as another local therapeutic modality in stage IIIA disease is mostly performed in a combined setting together with resection in a curative intent (neoadjuvant chemoradiotherapy, adjuvant radiotherapy). It is also used as either definitive therapy combined with chemotherapy for locally advanced disease or in unresectable tumours, medically inoperable patients or even those patients who refuse surgery. The goals of local radiotherapy are to maximize tumour control and to minimize toxicity of treatment $(7-12,138-141)$. In patients with stage IIIA disease, prophylactic cranial radiotherapy is not recommended $(8,142,143)$.

\section{Treatment approaches according to subgroups}

\section{Stage IIIA N2 NSCLC}

The subgroup N2 of stage IIIA disease has a poor 5-year overall survival rate $(30-32,144)$ and is divided into subsets according to the Robinson classification (145).

As Putora et al. showed, there is a lack of consensus in definition for resectable or limited N2 disease (144). The definition of nodal involvement varies across international guidelines and organizations, using categorizations of levels/ stations (1 to 14 ) or nodal zones [supraclavicular, upper, aortopulmonary (AP), subcarinal, lower, hilar/interlobar and peripheral zone] (60). Especially for the term of bulky $\mathrm{N} 2$ no holistic definition exists and indication for surgery in stage IIIA bulky N2 remains highly controversial (38).

According to the NCCN Clinical Practice Guidelines in Oncology for NSCLC (7) single lymph nodes smaller than $3 \mathrm{~cm}$ can be considered for a multimodality approach that includes surgical resection, but the authors do not define bulky disease. While the National Cancer Institute (10) as well as the American College of Chest Physicians EvidenceBased Clinical Practice Guidelines for NSCLC (12) classify bulky disease involving multiple nodal stations as unresectable or a contraindication to surgery, the German guidelines S3-Leitlinie-Prävention, Diagnostik, Therapie und Nachsorge des Lungenkarzinoms (9) address, that patients might not benefit from surgery, but overall give no clear recommendation. The National Institute for Health and Care Excellence (NICE) Guidelines for lung cancer (11) and the European Society for Medical Oncology (ESMO) Clinical Practice Guidelines for early and locally advanced NSCLC (8) do not refer to bulky disease at all in their guidelines.

The INT 0139, ESPATUTE, EORTC 08941 trials and Decaluwé et al. compared neoadjuvant therapy plus surgery with other bimodality approaches including combinations of chemotherapy and radiotherapy and showed similar 5 -year overall survival rates ranging from $14 \%$ to $44 \%$ (30-35). Decaluwé et al. also showed that there is no significant difference in 5-year survival in ypN1a compared to ypN2a1-2 (40.6\% vs. 37\%, $\mathrm{P}=0.89)$ as well as in ypN01a compared to ypN2a1-2 (49.1\% vs. $37 \%, \mathrm{P}=0.52)$. In a merged subgroup of ypN0, ypN1a and ypN2a1-2 compared to ypN2b alone the 5 -year survival rates significantly differed 
(43.4\% vs. $0 \%, \mathrm{P}<0.0005$ ), the same for the comparison of the same merged subgroup with ypN2b-3 (43.4\% vs. $7.1 \%$, $\mathrm{P}<0.001)$, emphasizing the prognostic impact of mediastinal nodal involvement of multiple levels (34).

Resected tumours in patients with mediastinal downstaging following neoadjuvant therapy as well as a highly selected cases of persistent $\mathrm{N} 2 \mathrm{a} 1-2$ disease show a satisfying survival with 5 -year survival rates around $30 \%$ (34,36,146-148), surprisingly up to $42 \%$ (148) in case of complete or R0 resection in persistent $\mathrm{N} 2 \mathrm{a} 1-2$ disease. Non-responders have a disappointing survival.

Radiotherapy compared to surgery after induction or neoadjuvant chemotherapy offers similar survival benefits in patients with resectable stage IIIA tumours (31).

\section{T1-2 N2 recognized by staging prior to resection (Robinson $\left.\mathrm{III} A_{3}\right)$}

This subgroup contains T1 and T2 tumours with single or multiple non-bulky $\mathrm{N} 2$ disease diagnosed by complete staging prior to any therapy.

If there is $\mathrm{N} 2 \mathrm{a} 1$ or $\mathrm{N} 2 \mathrm{a} 2$ status in stage IIIA $_{3}$ in medically operable patients with resectable tumours, combined modality treatment approaches are appropriate. Corresponding approaches are resection followed by adjuvant chemotherapy, neoadjuvant chemotherapy followed by surgery and optional radiation therapy or even potentially neoadjuvant chemoradiotherapy $(38,149,150)$.

In resectable tumours, surgery improves long-term survival and is the preferred treatment $(34,36)$. Especially in patients with response due to (neoadjuvant or induction) chemotherapy $(26,36)$. As long as feasible, radical anatomical resection is recommended but indication for pneumonectomy after neoadjuvant chemoradiotherapy is controversial but might be appropriate in carefully selected patients (30,151-157). Adjuvant radiotherapy following complete resection with MLND should be discussed (9).

Neoadjuvant chemotherapy may accomplish a reduction in tumour size, making resection more feasible and eradicate micrometastatic disease. Neoadjuvant chemotherapy also significantly improves overall survival, time to distant recurrence and recurrence-free survival (26,158-165). A combined neoadjuvant chemoradiotherapy may achieve nodal clearance, therefore, being appropriate in highly selected cases (T3 or T4 tumours), but indication remains controversial in T1-2 N2 disease (13,26,149,151,165-168). There is minimal risk of additional surgical complications following neoadjuvant chemoradiotherapy $(49,146,169-173)$.
Data and results comparing adjuvant versus neoadjuvant chemotherapy in early and locally advanced disease are controversial. Recommendations on timing of chemotherapy varies, but some studies suggest that neoadjuvant chemotherapy is better tolerated than adjuvant chemotherapy and compliance to treatment is higher (26,129,159,160,174-181). An explanation for this might be the comorbidities and/or an incomplete recovery after surgery, overall making it difficult for these patients to tolerate additional adjuvant chemotherapy (182). Because of the heterogeneity of N2 disease included in studies, it is even more difficult to account whether neoadjuvant or adjuvant chemotherapy is superior in these patients.

Reevaluation after neoadjuvant treatment including restaging is important for prognosis. Patients with good therapy response and disease regression with negative lymph nodes (hilar and especially mediastinal) documented in the PET scan have a better survival $(34,183)$. Additionally, downstaging of $\mathrm{N} 2$ status could be pathologically evaluated to be confirmed after negative PET scan in restaging. But some authors postulate that as long as progressive disease was excluded and the tumour deemed resectable prior to neoadjuvant treatment there is no consequence of an additional or even initial invasive mediastinal restaging (mediastinoscopy or EBUS/EUS) if complete resection is anticipated, especially because false negative rates can be up to $25 \%$ (mediastinoscopy) or $15 \%$ (EBUS/EUS), respectively $(22,184)$. Progressive disease after neoadjuvant therapy should not be considered for surgery. Therefore, local radiotherapy with or without systemic therapy might be discussed $(7-11,13,26)$.

\section{Multi-level IIIA $A_{3}$ and IILA}

In stage $\mathrm{IIIA}_{4}$ or if there is N2b (multi-level) lymph node involvement in stage $\mathrm{IIIA}_{3}$ in medically operable patients with resectable tumour, definitive concurrent chemoradiotherapy is the preferred approach, but surgery might be still an option in carefully selected patients $(7-9,34,36,37)$. In resectable stage $\mathrm{IIIA}_{3}$ or potentially stage $\mathrm{IIIA}_{4}$ disease radical en-bloc resection following neoadjuvant chemotherapy can be an appropriate strategy $(7-9,34,36)$.

After neoadjuvant chemoradiotherapy, regression of the primary tumour and mediastinal downstaging are independent prognostic factors for long term survival $(9,34,36,37,185,186)$. Nevertheless, although persistence 
of N2 nodes is present, the initial trimodality approach including surgery should be continued, as long as disease progression is excluded after restaging (34,36,187-189). The surgical approach is also appropriate in multi-level N2 involvement in highly selected cases, even if these cases are associated with lower 5-year survival compared to N2a1 or N2a2 disease (7-9,26,34,36,37).

Sensitivity and specificity as well as positive and negative predictive values of PET scan after neoadjuvant treatment is limited. Therefore, FDG-avidity in ycN2 nodes does not precisely correspond with ypN2 status and incorrect diagnosis through over- or even underdiagnosis may be provided $(37,190)$. Hence, when a neoadjuvant setting is chosen and disease progression is excluded after restaging, proceeding with a radical resection even in case of persistent $\mathrm{N} 2$ disease is appropriate without invasive mediastinal reevaluation (see also above) $(22,184,191)$.

\section{Bulky N2 disease at staging (Robinson $\mathrm{III}_{4}$ )}

In the heterogeneous group of $\mathrm{N} 2$ nodal disease, the term bulky $\mathrm{N} 2$ also received a heterogeneity of definitions, even among guidelines $(7,9,12,144,192,193)$. It is mostly defined as mediastinal lymph nodes exceeding diameters of 3 or $2-3 \mathrm{~cm}$. Bulky N2 is rarely evaluated separately as a subgroup of patients with N2 disease. Some authors reported a negative impact on survival $(36,194)$, while international guidelines classify bulky disease as unresectable or even a contraindication for surgery. In these guidelines, patients mentioned to most likely benefit from surgery in IIIA N2 disease are those with single station N2 involvement and non-bulky lymph nodes, for other subgroups indication for surgery in a multimodality setting remains controversial and might be applicable in highly selected cases. Reported 5-year survival rates for bulky N2 disease are 2-5\% (10).

\section{Incidental or unforeseen $\mathrm{N} 2$ (Robinson III $A_{1}$ and III $A_{2}$ )}

This subgroup contains T1 and T2 tumours with N2 disease found macroscopically during resection or microscopically in frozen section analysis intraoperatively or in the final pathology examination of the resected specimen. In these patients, resection is mostly indicated because of clinical stage I or II NSCLC.

For completely resected stage IIIA $_{1}$ and stage IIIA $_{2}$ tumours, adjuvant chemotherapy significantly improves overall survival and remains the standard of care (195-205). If not given preoperatively, additional postoperative radiation therapy (PORT) in $\mathrm{N} 2$ disease may improve survival, but remains controversial and mostly optional (163,206-211). Adjuvant radiotherapy might be considered in selected patients to reduce the risk of local recurrence in multiple nodal station involvement, with performed MLNS in IIIA $_{1}$, extracapsular tumour spread or as described below, in positive resection margins $(7-11,210,212)$. If chemoradiotherapy is used in a trimodality approach following surgery, radiotherapy should be performed sequentially after chemotherapy. Adjuvant radiotherapy is not recommended for stage I and II, because it has been shown to have a detrimental effect on long-term survival in these patients (203).

\section{Incomplete resection, unresectable or inoperable stage IIIA N2 disease}

In $\mathrm{R} 1$ resection, either sequential or concurrent chemoradiotherapy is recommended, whereas in $\mathrm{R} 2$ resection concurrent chemoradiotherapy is the recommended adjuvant approach. In R1 situation reresection might be discussed, if feasible $(7,9,213,214)$.

According to the prognostic impact of the R-status, survival of uncertain resection or R-classification ranges between that of R0 and R1 resected tumours (215).

In case surgery is not feasible based on inoperability or unresectable stage IIIA N2 tumours, these patients can be treated by definitive chemoradiotherapy without surgery $(7-11,13,26)$.

\section{T3 N1}

Locally advanced tumours classified as T3 are 5 to $7 \mathrm{~cm}$ in size or directly invading the parietal pleura, the chest wall (including sulcus superior tumours), the phrenic nerve and/or the parietal pericardium. T3 also includes tumours with separate nodule(s) in the same lobe, which is discussed separately below. T3 tumours are potentially resectable even with present chest wall, pericardium or phrenic nerve invasion. Trials evaluating survival rates and outcome of this heterogeneous group often include $\mathrm{T} 3_{\text {Satell }}$ tumours with a much better survival, resulting in general survival rates with less validity for the whole group of stage IIIA T3 N1 disease. Isolated subgroups are described below.

\section{Pericardial or phrenic nerve involvement}

Resection of tumours with pericardial involvement with 
subsequent net reconstruction is feasible in most of the cases. Same applies for phrenic nerve involvement with potential later phrenoplasty or phrenoplication if indicated. Inoue et al. reported 5 -year survival rates of $43 \%$ for patients with T3 tumours and pericardium invasion (67).

\section{Chest wall involvement}

Depending on extent and location of the locally advanced tumours such as T3 $\mathrm{N} 1$ or even T4 N0-1 with either chest wall involvement or in sulcus superior tumours, which are potentially resectable, provided that a complete resection (R0) can be performed, a combined modality approach with concurrent neoadjuvant chemotherapy or chemoradiotherapy followed by radical en-bloc resection after multidisciplinary evaluation is recommended in selected cases. Complete resection followed by adjuvant chemotherapy with or without radiation is also appropriate in selected cases of tumours invading the chest wall, if not classified as sulcus superior tumours (7-9,13,216,217). Surgical planning and reevaluation after chemoradiotherapy have to be emphasized, regarding older reported complete resection rates of $64 \%$ and $39 \%$ in $\mathrm{T} 3 \mathrm{~N} 0$ and $\mathrm{T} 4 \mathrm{~N} 0$ tumours, respectively (218).

Survival of patients with stage IIIA NSCLC with T3 N1 tumours and chest wall invasion highly depends on completeness of resection and extent of nodal involvement. The depth of chest wall invasion is less important. Associated 5-year survival rates after R0 resection range from $20-40 \%$ for T3 N1 $(13,38-43)$, whereas 5 -year survival rates for T3 N2 does not exceed 10\% (42).

\section{Sulcus superior tumours}

Sulcus superior tumours according to their extent can be classified as T3 (involvement of inferior branches of the brachial plexus such as C8 and/or T1) or as T4 if vertebral or spinal canal invasion, involvement of the subclavian vessels and/or brachial plexus (C8 and above) is present (60). Anatomical resection with at least a lobectomy following neoadjuvant chemoradiotherapy in selected patients offers the best survival benefit for these patients $(13,219,220)$. Using such an aggressive curative and surgical approach in sulcus superior tumours in a trimodality setting can reach 5-year survival rates around $50 \%$ (44) up to nearly $80 \%$ after complete resection $(57,58)$, with small up to no differences between T3 or T4 tumours. N0 or N1 status did not significantly affect overall survival in these trials, but mediastinal lymph node involvement is associated with poor survival after resection $(13,44-56)$.

\section{T4 NO-1}

Tumours bigger than $7 \mathrm{~cm}$ in greatest dimension, lung cancer of any size invading one or more of the following: mediastinum, diaphragm, heart, great vessels, recurrent laryngeal nerve, carina, trachea, esophagus, vertebral body or tumours with additional nodule(s) in a different ipsilateral lobe are classified as the heterogenous group of $\mathrm{T} 4$.

There is only limited data regarding extended surgical resections of these subgroups of T4 tumours and there is no consensus in international guidelines which subgroups should be classified as unresectable. Even invasion of the carina and trachea, the left atrium, the superior vena cava (SVC), one or multiple vertebral bodies, the aorta or combination of these may allow resection as discussed below. However, only inconsistent data and small retrospective case series are reported for the specific subgroups (69). Same as for T3 tumours, in trials including patients with locally advanced or only stage IIIA disease, $\mathrm{T} 4$ tumours are summarized including $\mathrm{T} 4_{\text {Ipsi Nod }}$ resulting in survival rates that are much better than these reported for the specific subgroups described below.

Most of these patients with $\mathrm{T} 4_{\text {Inv }}$ tumours involving the structures mentioned above have positive mediastinal lymph nodes, making this entity of $\mathrm{T}_{\text {Inv }} \mathrm{N} 0-1$ tumours a rarity. In general, these patients with locally advanced $\mathrm{T} 4_{\mathrm{Inv}}$ are not considered good candidates for surgery. Therefore, these patients should be discussed in multidisciplinary boards after completed staging with a careful indication for surgery with only a subset of patients being candidates with a beneficial outcome after resection. Only if complete $\mathrm{R} 0$ resection is ensured, these patients can benefit from a surgical approach in a bi- or trimodality setting with neoadjuvant treatment. There is no consensus regarding these locally advanced tumours, whether neoadjuvant chemotherapy or chemoradiotherapy is superior to immediate surgical en-bloc resection $(13,59,69,82,221,222)$. These extensive en-bloc resections should be performed in specialized centers only (13).

Radical en-bloc resection in a combined modality approach appears to be beneficial compared to definitive chemoradiotherapy alone $(7,9,13)$. In a planned bi- (without surgery) or trimodality approach, restaging and surgical reevaluation will show if resection is still or is now feasible. If the tumour is still or newly confirmed to be unresectable, adjuvant treatment with durvalumab or consolidation chemotherapy is an option (7). 
When considering surgical resection in patients with T3-4 tumours, mediastinal staging is key because mediastinal nodal involvement is associated with poor prognosis (69). Patients with T3-4 N2 disease are not surgical candidates, same as patients, where incomplete resection is inevitable. In patients with $\mathrm{T} 3$ and $\mathrm{T} 4$ tumours with occult N2 status after surgery (stage IIIB), sequential or concurrent chemoradiotherapy should follow resection (7). Therefore, it is important to emphasize that local invasion of the tumour is not nearly as predictive of outcome and survival as N2 status $(39,40,43,223)$.

In $\mathrm{R} 1$ resection of these locally advanced tumours (T3 N1, T4 N0-1) either sequential or concurrent chemoradiotherapy is recommended, whereas in $\mathrm{R} 2$ resection concurrent chemoradiotherapy is the preferred adjuvant treatment approach $(7,214)$. Incomplete resection in general is associated with a very poor prognosis.

\section{$T 4_{\text {Inv }}$-mediastinum}

Mediastinal involvement may include other central structures. Tumours with mediastinal fat or mediastinal pleural invasion are potentially resectable (59). In case this invasion of the mediastinal fat is only limited to the hilum, these tumours might be classified as T2a or T2b (60). Watanabe et al. reported similar survival rates without significant difference between $\mathrm{T} 4_{\text {Inv }}$ tumours invading only the mediastinal fat compared to those with other mediastinal organ invasion, $36.1 \%$ for mediastinal fat invasion vs. $36.2 \%$ for invasion of other structures (61). Other authors reported different survival, but this subgroup contains a heterogeneity of extent of mediastinal invasion, making comparisons more difficult $(53,62)$. On the contrary, resectability is highly depending on mediastinal organs or structures involved (see below).

\section{$T 4_{\text {Inv }}$-diaphragm}

In tumours invading the diaphragm, latter can generally be partially or even completely resected. Reconstruction can be achieved using direct sutures in smaller or prosthetic material in larger defects. There is only a small amount of reported series with $\mathrm{T} 4_{\text {Inv }}$ tumours invading the diaphragm and most of them are older case series. Yokoi et al. reported 5 -year survival rates of $14-33 \%$ depending on depth of diaphragm invasion, while other authors showed similar outcome (63-68).

\section{$T 4_{\text {Inv }}$ - heart and great vessels}

The great vessels mentioned in the TNM classification include the superior and inferior vena cava, the pulmonary trunk, the intrapericardial parts of the left and right pulmonary artery and the intrapericardial parts of the superior and inferior left and right pulmonary veins (60).

\section{$T 4_{\text {Inv }}$ - left atrium and pulmonary veins}

Usually, NSCLC invading the heart is not amenable to resection, but there is the exception of left atrial and/or intrapericardial superior and inferior vein involvement. $\mathrm{T}_{\text {Inv }}$ tumours invading the left atrium and its inflow are potentially resectable with reported 5 -year survival rates around $15-26 \%(13,69,70)$. Involved hilar or mediastinal lymph nodes are associated with poorer survival and resections may be performed with or even without cardiopulmonary bypass (71-84).

\section{$T 4_{I n v}-S V C$}

Patients with $T 4_{\text {Inv }}$ tumours invading the SVC may be candidates for radical resection. The SVC can be partially or completely resected and reconstructed and prosthetic replacement of the SVC can be safely performed. Five-year survival rates are reported around $25-40 \%$ $(13,53,69,78,83-96)$.

\section{$T 4_{\text {Inv }}$-inferior vena cava}

There are only very few cases reported with involvement of the inferior vena cava following radical resection and specific results are unavailable (83).

\section{T4 $4_{\text {Inv }}-$ pulmonary artery}

Involvement of the main pulmonary artery (pulmonary trunk) or its intrapericardial portions often require pneumonectomy (97). Depending on extent, resection and reconstruction of the pulmonary artery is technically feasible $(53,70,84,97,98)$. No specific survival rates are reported in $\mathrm{T}_{\text {Inv }}$ tumours of this subgroup.

\section{$T 4_{\text {Inv }}-$ aorta}

The aorta can be infiltrated by NSCLC. Preoperative endovascular stent placement allows a safe and complete 
resection of these tumours with better outcome than subaortic dissection $(69,99,100)$. Five-year survival rates are reported around $17-50 \%(13,69,81,84,88,101,102)$ up to $70 \%(103,104)$ in smaller case series. Absence of nodal involvement is associated with better outcome (13).

\section{T4 $4_{\text {Inv }}$-recurrent laryngeal nerve}

Resection of invaded recurrent laryngeal nerve by $\mathrm{T} 4_{\text {Inv }}$ tumours is technically feasible and patients should be carefully selected. Reported data is involving only few patients with less information given about their outcome, making interpretation of data of this subgroup extremely difficult (70).

\section{$T 4_{\text {Inv }}$-carina and trachea}

Based on extent of tracheal involvement, carinal and tracheal resections are potentially feasible. Reported 5-year survival rates are around $33 \%$ up to $44 \%$ (13), with lymph node involvement having a strong influence on survival $(38,53,70,84,105-110)$.

\section{$T 4_{\text {Inv }}$-esophagus}

For tumours invading the esophagus and where resection was attempted, there are only few reported cases in larger series summarizing $\mathrm{T}_{\text {Inv }}$ tumours. Yildizeli et al. and Pitz et al. reported a very small number of patients with only resection of the muscular layer of the esophagus, where no invasion of the mucosa was present $(53,70)$. Because of poor outcome of these subgroup, invasion of the esophagus is generally stated as a contraindication for surgery.

\section{T4 $4_{\text {Inv }}$-vertebral bodies and spine}

Although T4 tumours involving vertebral bodies are usually classified as unresectable, several case series reported good long-term survival. Therefore, in highly selected cases these patients may be candidates for radical resection followed by reconstruction including thoracic and spine surgeons to perform laminectomy, single or multi hemivertebrectomy or even total resection of one up to three vertebral bodies $(38,111)$. Reported 5 -year survival rates are around $21-47 \%$ $(13,111-119)$ up to $79.6 \%$ in meticulously selected patients with R0 resection following neoadjuvant chemoradiotherapy and complete response $(57,58)$.

\section{$T 3_{\text {Satell }}$ and $T 4_{I p s i \mathrm{Nod}}$}

For patients with T3 disease with separate tumour nodule(s) in the same lobe $\left(\mathrm{T} 3_{\text {Satell }}\right)$ or in $\mathrm{T} 4$ disease with tumour nodule(s) in a different ipsilateral lobe $\left(\mathrm{T}_{\text {Ipsi Nod }}\right)$ without any systemic metastasis, surgery with optional adjuvant chemotherapy is recommended as in smaller singular tumours (treatment strategy stage-specific for dominant tumour) $(44,224,225)$. Lee et al. reported 5 -year survival rates about $30 \%$ for $\mathrm{T} 3_{\text {Satell }}$ and $\mathrm{T} 4_{\text {Ipsi Nod }}$ tumours without significant difference between each other (226). However, Kozower et al. reported an average 5-year survival rate of $37 \%$ for $\mathrm{T} 3_{\text {Satell }}$ and $19 \%$ for $\mathrm{T} 4_{\text {Ipsi Nod }}$ tumours (13), whereas Blasberg et al. stated an average overall $40 \% 5$-year survival rate for $\mathrm{T} 3_{\text {Satell }}\left(50 \%\right.$ for N0) and $30 \%$ for $\mathrm{T} 4_{\text {Ipsi Nod }}$ (40\% for N0) (44).

According to Nagai et al. survival significantly differs depending on nodal involvement in $\mathrm{T} 3_{\text {Satell }}$ tumours, resulting in 5-year survival rates of $45.8 \%$ for pN0, $25.3 \%$ for $\mathrm{pN} 1$ and $11.1 \%$ for $\mathrm{pN} 2$ status (227). Port et al. showed, that $\mathrm{T} 3_{\text {Satell }} \mathrm{N} 0$ disease (in Port et al. classified as T4 according to $6^{\text {th }}$ edition of TNM staging system) has 5 -year survival rates similar to early stages of NSCLC (228). It is important to note, that stage IIIA NSCLC is only including $\mathrm{T} 3_{\text {Satell }} \mathrm{N} 1$ but also $\mathrm{T} 4_{\text {Ipsi Nod }} \mathrm{N} 0-1$ disease.

For T4 $4_{\text {Ipsi Nod }}$ N0, Blasberg et al. noted an average 5-year survival rate of $40 \%$ (44). Nagai et al. reported significant survival differences between $\mathrm{pN} 0$ and $\mathrm{pN} 1$ as well as $\mathrm{pN} 0$ compared to pN2. No significant difference was shown between pN1 and pN2 disease in $\mathrm{T}_{\text {Ipsi Nod }}$ tumours. Five-year survival rates were reported as follows: $42.1 \%$ for $\mathrm{pN} 0,7.9 \%$ for $\mathrm{pN} 1$ and $10.0 \%$ for $\mathrm{pN} 2$ status and $46.2 \%$ for completely (R0) resected T4 $4_{\text {Ipsi Nod }} \mathrm{N} 0$ disease (227).

\section{Unresectable T3/T4 and inoperable patients}

For unresectable $\mathrm{T} 3$ or $\mathrm{T} 4$ tumours, definitive concurrent chemoradiotherapy is a non-surgical alternative (7). Based on performance status in functional and medical inoperable patients, definitive treatment is individually. Concurrent or sequential chemoradiotherapy in patients with low comorbidities or ECOG $<2$ or even definitive radiotherapy alone in case of severe comorbidities are alternative strategies (9). Definitive concurrent chemoradiotherapy is preferred compared to the sequential regimen. Concurrent chemoradiotherapy provides a greater survival benefit but on another side bears an increased toxic effect. If for any reason a concurrent regimen is not possible, chemotherapy 
followed by definitive radiotherapy (sequential approach) is a valid alternative $(8,122-128)$.

Radiotherapy alone in locally advanced disease is mostly used in a palliative setting in stage IIIA disease. In these patients, radiotherapy may be beneficial in palliating symptoms of local tumour involvement (pain, hemoptysis and hemoptoe, recurrent laryngeal nerve paralysis and tracheal, esophageal or SVC compression). Long-term outcomes are poor based on local and systemic recurrence (10).

\section{The role of VATS anatomical resection in locally advanced NSCLC}

In the last decades thoracoscopic pulmonary surgery and its technique has advanced offering surgical resection for patients who previously might not have been considered candidates for radical resection (7). Compared to the conventional open thoracotomy, the reasonable technical feasibility, safety and advantages of minimal invasive approaches such as video-assisted thoracic surgery (VATS), especially in major anatomical pulmonary resections performed by VATS, has been demonstrated. It has also been illustrated, that VATS lobectomy is potentially superior compared to open lobectomy (7,229-246). Additionally, published data shows a trend towards improved tolerance of adjuvant chemotherapy following VATS anatomical resections with higher compliance rate and fewer delayed or reduced doses $(244,247)$. Data also shows that most resected lung cancers by robotic-assisted thoracic surgery (RATS) are in early stage disease. Furthermore, it has been shown, that RATS seems to be accompanied by higher hospital costs and longer operating times, but without any differences in adverse events $(248,249)$. Therefore, RATS is of limited importance in resection of stage IIIA disease and might only be indicated in highly selected cases.

Anatomical resections performed by VATS are an appropriate therapeutic approach in operable patients with resectable tumours, even in locally advanced stage IIIA, as far as there are no compromises of oncological principles and complete $\mathrm{R} 0$ en-bloc resection is feasible $(7,229,245,246,250)$. VATS has also been shown to be a safe and feasible approach following neoadjuvant chemotherapy in these locally advanced tumours, even in limited sulcus superior tumours $(170,171,251,252)$.

As discussed earlier, it could not be shown so far, whether neoadjuvant or adjuvant chemotherapy is superior approaching clinical stage IIIA N2 disease and the commonly held view favouring neoadjuvant chemotherapy is still vague (177).

Preoperative chemotherapy as well as radiotherapy can induce local tissue inflammation and edema, resulting in tissue adhesions with partially fused interlobar fissure, hilar and mediastinal fibrosis with anthracofibrosis and perivascular/peribronchial lymph node calcification as well as increased tissue and especially vascular fragility. Thus, making surgery in general more difficult and adhesiolysis and anatomic dissection more tedious with potentially higher operation time $(35,170,171,253)$. These apply for open and for minimally invasive thoracic surgery.

Villamizar et al. noticed an increased complication rate in patients undergoing VATS resection followed by neoadjuvant chemotherapy compared to non-preoperative treatment (254). Since safety has always been of highest importance for surgeons, this implies that thoracic surgeons may favor adjuvant therapy, avoiding possible tedious dissection. On the contrary, other authors confirmed the safety and feasibility of VATS following neoadjuvant treatment without an increase of postoperative complications (170-173). Therefore, it is important to highlight the uniportal VATS approach, resulting in a direct view, the same way as provided due to open thoracotomy $(172,173)$, with an easier access for dense adhesions after neoadjuvant treatment in locally advanced NSCLC.

Regarding a possible publication bias with cases reported only after uneventful postoperative courses and based on the heterogeneity of stage IIIA disease, it remains unclear, whether neoadjuvant or adjuvant treatment should be favored, when minimally invasive thoracic surgery is planned.

\section{Conclusions}

Stage IIIA NSCLC comprises a very heterogeneous group of different subsets of disease with large differences in therapeutic approaches and outcome. Therefore, it is important to discuss each case in a multidisciplinary setting following complete staging to form an individual recommendation in a multimodality treatment regimen.

\section{Acknowledgments}

Funding: None. 


\section{Footnote}

Provenance and Peer Review: This article was commissioned by the editorial office, Current Challenges in Thoracic Surgery for the series "Controversies in the Management of Stage IIIA Non-Small-Cell Lung Cancer". The article has undergone external peer review.

Reporting Checklist: The authors have completed the Narrative Review reporting checklist. Available at https:// ccts.amegroups.com/article/view/10.21037/ccts-20-97/rc

Peer Review File: Available at https://ccts.amegroups.com/ article/view/10.21037/ccts-20-97/prf

Conflicts of Interest: All authors have completed the ICMJE uniform disclosure form (available at https://ccts. amegroups.com/article/view/10.21037/ccts-20-97/coif). The series "Controversies in the Management of Stage IIIA Non-Small-Cell Lung Cancer" was commissioned by the editorial office without any funding or sponsorship. FM served as the unpaid Guest Editor of the series. GJK serves as an unpaid editorial board member of Current Challenges in Thoracic Surgery from September 2019 to August 2023. The authors have no other conflicts of interest to declare.

Ethical Statement: The authors are accountable for all aspects of the work in ensuring that questions related to the accuracy or integrity of any part of the work are appropriately investigated and resolved.

Open Access Statement: This is an Open Access article distributed in accordance with the Creative Commons Attribution-NonCommercial-NoDerivs 4.0 International License (CC BY-NC-ND 4.0), which permits the noncommercial replication and distribution of the article with the strict proviso that no changes or edits are made and the original work is properly cited (including links to both the formal publication through the relevant DOI and the license). See: https://creativecommons.org/licenses/by-nc-nd/4.0/.

\section{References}

1. The International Agency for Research on Cancer (IARC). Latest global cancer data: Cancer burden rises to 18.1 million new cases and 9.6 million cancer deaths in 2018 . Geneva: World Health Organization (WHO), 2018.

2. Howlader N, Noone AM, Krapcho M, et al. SEER Cancer
Statistics Review, 1975-2016, National Cancer Institute. Bethesda, MD. Based on November 2018 SEER data submission, posted to the SEER web site, April 2019. [Updated 14 February 2020, accessed 15 March 2020]. Available online: https://seer.cancer.gov/csr/1975_2016/

3. Travis WD, Brambilla E, Nicholson AG, et al. The 2015 World Health Organization Classification of lung tumors: impact of genetic, clinical and radiologic advances since the 2004 Classification. J Thorac Oncol 2015;10:1243-60.

4. Detterbeck FC, Boffa DJ, Kim AW, et al. The Eighth Edition Lung Cancer Stage Classification. Chest 2017;151:193-203.

5. Goldstraw P, Chansky K, Crowley J, et al. The IASLC Lung Cancer Staging Project: Proposals for Revision of the TNM Stage Groupings in the Forthcoming (Eighth) Edition of the TNM Classification for Lung Cancer. J Thorac Oncol 2016;11:39-51.

6. Yun JK, Lee GD, Kim HR, et al. Validation of the 8th edition of the TNM staging system in 3,950 patients with surgically resected non-small cell lung cancer. J Thorac Dis 2019;11:2955-64.

7. Ettinger DS, Wood DE, Aisner DL, et al. Non-Small Cell Lung Cancer, Version 3.2020, NCCN Clinical Practice Guidelines in Oncology. [Published 11 February 2020, accessed 15 March 2020]. Available online: https://www. nccn.org/professionals/physician_gls/pdf/nscl.pdf

8. Postmus PE, Kerr KM, Oudkerk M, et al. Early and locally advanced non-small-cell lung cancer (NSCLC): ESMO Clinical Practice Guidelines for diagnosis, treatment and follow-up. Ann Oncol 2017;28:iv1-21.

9. Leitlinienprogramm Onkologie (Deutsche Krebsgesellschaft, Deutsche Krebshilfe, AWMF): Prävention, Diagnostik, Therapie und Nachsorge des Lungenkarzinoms, Langversion 1.0. AWMFRegisternummer: 020/007OL. [Published February 2018, accessed 15 March 2020]. Available online: http://leitlinienprogramm-onkologie.de/ Lungenkarzinom.98.0.html

10. PDQ ${ }^{\circledR}$ Adult Treatment Editorial Board. PDQ NonSmall Cell Lung Cancer Treatment. Bethesda, MD: National Cancer Institute. [Updated 13 March 2020, accessed 21 March 2020]. Available online: https:// www.cancer.gov/types/lung/hp/non-small-cell-lungtreatment-pdq

11. National Institute for Health and Care Excellence. Lung cancer: diagnosis and management (NICE guideline 122). [Published 28 March 2019, accessed 21 March 2020]. Available online: https://www.nice.org.uk/guidance/ 
NG122

12. Silvestri GA, Gonzalez AV, Jantz MA, et al. Methods for staging non-small cell lung cancer: diagnosis and management of lung cancer, 3rd ed: American College of Chest Physicians evidence-based clinical practice guidelines. Chest 2013;143:e211S-50S.

13. Kozower BD, Larner JM, Detterbeck FC, et al. Special treatment issues in non-small cell lung cancer: diagnosis and management of lung cancer, 3rd ed: American College of Chest Physicians evidence-based clinical practice guidelines. Chest 2013;143:e369S-99S.

14. Annema JT, van Meerbeeck JP, Rintoul RC, et al. Mediastinoscopy vs endosonography for mediastinal nodal staging of lung cancer: a randomized trial. JAMA 2010;304:2245-52.

15. Ernst A, Eberhardt R, Krasnik M, et al. Efficacy of endobronchial ultrasound-guided transbronchial needle aspiration of hilar lymph nodes for diagnosing and staging cancer. J Thorac Oncol 2009;4:947-50.

16. Rintoul RC, Tournoy KG, El Daly H, et al. EBUS-TBNA for the clarification of PET positive intra-thoracic lymph nodes-an international multi-centre experience. J Thorac Oncol 2009;4:44-8.

17. Defranchi SA, Edell ES, Daniels CE, et al. Mediastinoscopy in patients with lung cancer and negative endobronchial ultrasound guided needle aspiration. Ann Thorac Surg 2010;90:1753-7.

18. Medford AR, Bennett JA, Free CM, et al. Mediastinal staging procedures in lung cancer: EBUS, TBNA and mediastinoscopy. Curr Opin Pulm Med 2009;15:334-42.

19. De Leyn P, Dooms C, Kuzdzal J, et al. Revised ESTS guidelines for preoperative mediastinal lymph node staging for non-small-cell lung cancer. Eur J Cardiothorac Surg 2014;45:787-98.

20. Gonzalez-Stawinski GV, Lemaire A, Merchant F, et al. A comparative analysis of positron emission tomography and mediastinoscopy in staging non-small cell lung cancer. J Thorac Cardiovasc Surg 2003;126:1900-5.

21. Tournoy KG, Maddens S, Gosselin R, et al. Integrated FDG-PET/CT does not make invasive staging of the intrathoracic lymph nodes in non-small cell lung cancer redundant: a prospective study. Thorax 2007;62:696-701.

22. Rocco G, Nason K, Brunelli A, et al. Management of Stage IIIA (N2) Non-Small Cell Lung Cancer: A Transatlantic Perspective. Ann Thorac Surg 2016;101:1247-50.

23. Asamura H, Chansky K, Crowley J, et al. The International Association for the Study of Lung Cancer Lung Cancer Staging Project: Proposals for the Revision of the N Descriptors in the Forthcoming 8th Edition of the TNM Classification for Lung Cancer. J Thorac Oncol 2015;10:1675-84.

24. Wei S, Asamura H, Kawachi R, et al. Which is the better prognostic factor for resected non-small cell lung cancer: the number of metastatic lymph nodes or the currently used nodal stage classification? J Thorac Oncol 2011;6:310-8.

25. Rena O. The "N"-factor in non-small cell lung cancer: staging system and institutional reports. J Thorac Dis 2016;8:3049-52.

26. Martins RG, D'Amico TA, Loo BW, Jr., et al. The management of patients with stage IIIA non-small cell lung cancer with N2 mediastinal node involvement. J Natl Compr Canc Netw 2012;10:599-613.

27. Hoang T, Xu R, Schiller JH, et al. Clinical model to predict survival in chemonaive patients with advanced non-small-cell lung cancer treated with third-generation chemotherapy regimens based on eastern cooperative oncology group data. J Clin Oncol 2005;23:175-83.

28. Kawaguchi T, Takada M, Kubo A, et al. Performance status and smoking status are independent favorable prognostic factors for survival in non-small cell lung cancer: a comprehensive analysis of 26,957 patients with NSCLC. J Thorac Oncol 2010;5:620-30.

29. Sculier JP, Chansky K, Crowley JJ, et al. The impact of additional prognostic factors on survival and their relationship with the anatomical extent of disease expressed by the 6th Edition of the TNM Classification of Malignant Tumors and the proposals for the 7th Edition. J Thorac Oncol 2008;3:457-66.

30. Albain KS, Swann RS, Rusch VW, et al. Radiotherapy plus chemotherapy with or without surgical resection for stage III non-small-cell lung cancer: a phase III randomised controlled trial. Lancet 2009;374:379-86.

31. Eberhardt WE, Pottgen C, Gauler TC, et al. Phase III study of surgery versus definitive concurrent chemoradiotherapy boost in patients with resectable stage IIIA(N2) and selected IIIB non-small-cell lung cancer after induction chemotherapy and concurrent chemoradiotherapy (ESPATUE). J Clin Oncol 2015;33:4194-201.

32. van Meerbeeck JP, Kramer GW, Van Schil PE, et al. Randomized controlled trial of resection versus radiotherapy after induction chemotherapy in stage IIIA-N2 non-small-cell lung cancer. J Natl Cancer Inst 2007;99:442-50.

33. Van Schil P, Van Meerbeeck J, Kramer G, et al. Morbidity 
and mortality in the surgery arm of EORTC 08941 trial. Eur Respir J 2005;26:192-7.

34. Decaluwé H, De Leyn P, Vansteenkiste J, et al. Surgical multimodality treatment for baseline resectable stage IIIA-N2 non-small cell lung cancer. Degree of mediastinal lymph node involvement and impact on survival. Eur J Cardiothorac Surg 2009;36:433-9.

35. Van Schil PE, Yogeswaran K, Hendriks JM, et al. Advances in the use of surgery and multimodality treatment for N2 non-small cell lung cancer. Expert Rev Anticancer Ther 2017;17:555-61.

36. Stefani A, Alifano M, Bobbio A, et al. Which patients should be operated on after induction chemotherapy for N2 non-small cell lung cancer? Analysis of a 7-year experience in 175 patients. J Thorac Cardiovasc Surg 2010;140:356-63.

37. Couñago F, Montemuiño S, Martin M, et al. Prognostic factors in neoadjuvant treatment followed by surgery in stage IIIA-N2 non-small cell lung cancer: a multiinstitutional study by the Oncologic Group for the Study of Lung Cancer (Spanish Radiation Oncology Society). Clin Transl Oncol 2019;21:735-44.

38. Nath SK, Bledsoe TJ, Decker RH. Curative intent treatment of stage III non-small cell lung cancer. In: Tanoue L, Detterbeck F. editors. Lung cancer: a practical approach to evidence-based clinical evaluation and management. St. Louis: Elsevier, 2018:83-98.

39. Downey RJ, Martini N, Rusch VW, et al. Extent of chest wall invasion and survival in patients with lung cancer. Ann Thorac Surg 1999;68:188-93.

40. Matsuoka H, Nishio W, Okada M, et al. Resection of chest wall invasion in patients with non-small cell lung cancer. Eur J Cardiothorac Surg 2004;26:1200-4.

41. Facciolo F, Cardillo G, Lopergolo M, et al. Chest wall invasion in non-small cell lung carcinoma: a rationale for en bloc resection. J Thorac Cardiovasc Surg 2001;121:649-56.

42. Stoelben E, Ludwig C. Chest wall resection for lung cancer: indications and techniques. Eur J Cardiothorac Surg 2009;35:450-6.

43. Harpole DH Jr, Healey EA, DeCamp MM Jr, et al. Chest wall invasive non-small cell lung cancer: patterns of failure and implications for a revised staging system. Ann Surg Oncol 1996;3:261-9.

44. Blasberg JD, Kim C, Chilakamarry S. Special types of lung cancer. In: Tanoue L, Detterbeck F. editors. Lung cancer: a practical approach to evidence-based clinical evaluation and management. St. Louis: Elsevier, 2018:131-46.
45. Rusch VW, Giroux DJ, Kraut MJ, et al. Induction chemoradiation and surgical resection for superior sulcus non-small-cell lung carcinomas: long-term results of Southwest Oncology Group Trial 9416 (Intergroup Trial 0160). J Clin Oncol 2007;25:313-8.

46. Kunitoh H, Kato H, Tsuboi M, et al. Phase II trial of preoperative chemoradiotherapy followed by surgical resection in patients with superior sulcus non-small-cell lung cancers: report of Japan Clinical Oncology Group trial 9806. J Clin Oncol 2008;26:644-9.

47. Doddoli C, D'Journo B, Le Pimpec-Barthes F, et al. Lung cancer invading the chest wall: a plea for en-bloc resection but the need for new treatment strategies. Ann Thorac Surg 2005;80:2032-40.

48. Rusch VW, Giroux DJ, Kraut MJ, et al. Induction chemoradiation and surgical resection for non-small cell lung carcinomas of the superior sulcus: Initial results of Southwest Oncology Group Trial 9416 (Intergroup Trial 0160). J Thorac Cardiovasc Surg 2001;121:472-83.

49. Kwong KF, Edelman MJ, Suntharalingam M, et al. Highdose radiotherapy in trimodality treatment of Pancoast tumors results in high pathologic complete response rates and excellent long-term survival. J Thorac Cardiovasc Surg 2005;129:1250-7.

50. Pourel N, Santelmo N, Naafa N, et al. Concurrent cisplatin/etoposide plus 3D-conformal radiotherapy followed by surgery for stage IIB (superior sulcus T3N0)/ III non-small cell lung cancer yields a high rate of pathological complete response. Eur J Cardiothorac Surg 2008;33:829-36.

51. Marra A, Eberhardt W, Pottgen C, et al. Induction chemotherapy, concurrent chemoradiation and surgery for Pancoast tumour. Eur Respir J 2007;29:117-26.

52. Detterbeck FC. Pancoast (superior sulcus) tumors. Ann Thorac Surg 1997;63:1810-8.

53. Yildizeli B, Dartevelle PG, Fadel E, et al. Results of primary surgery with T4 non-small cell lung cancer during a 25-year period in a single center: the benefit is worth the risk. Ann Thorac Surg 2008;86:1065-75; discussion 1074-5.

54. Gomez DR, Cox JD, Roth JA, et al. A prospective phase 2 study of surgery followed by chemotherapy and radiation for superior sulcus tumors. Cancer 2012;118:444-51.

55. Wright CD, Menard MT, Wain JC, et al. Induction chemoradiation compared with induction radiation for lung cancer involving the superior sulcus. Ann Thorac Surg 2002;73:1541-4.

56. Ginsberg RJ, Martini N, Zaman M, et al. Influence 
of surgical resection and brachytherapy in the management of superior sulcus tumor. Ann Thorac Surg 1994;57:1440-5.

57. Collaud S, Waddell TK, Yasufuku K, et al. Long-term outcome after en bloc resection of non-small-cell lung cancer invading the pulmonary sulcus and spine. J Thorac Oncol 2013;8:1538-44.

58. Yokomise H, Gotoh M, Okamoto T, et al. En bloc partial vertebrectomy for lung cancer invading the spine after induction chemoradiotherapy. Eur J Cardiothorac Surg 2007;31:788-90.

59. Yamanashi K, Menju T, Hamaji M, et al. Prognostic factors related to postoperative survival in the newly classified clinical T4 lung cancer. Eur J Cardiothorac Surg 2020;57:754-61.

60. Rami-Porta R, International Association for the Study of Lung Cancer. Staging Manual in Thoracic Oncology. North Fort Myers: Editorial Rx Press, 2016.

61. Watanabe S, Asamura H, Miyaoka E, et al. Results of T4 surgical cases in the Japanese Lung Cancer Registry Study: should mediastinal fat tissue invasion really be included in the T4 category? J Thorac Oncol 2013;8:759-65.

62. Rendina EA, Venuta F, De Giacomo T, et al. Induction chemotherapy for T4 centrally located non-small cell lung cancer. J Thorac Cardiovasc Surg 1999;117:225-33.

63. Yokoi K, Tsuchiya R, Mori T, et al. Results of surgical treatment of lung cancer involving the diaphragm. J Thorac Cardiovasc Surg 2000;120:799-805.

64. Galetta D, Borri A, Casiraghi M, et al. Outcome and prognostic factors of resected non-small-cell lung cancer invading the diaphragm. Interact Cardiovasc Thorac Surg 2014;19:632-6; discussion 636.

65. Riquet M, Porte H, Chapelier A, et al. Resection of lung cancer invading the diaphragm. J Thorac Cardiovasc Surg 2000;120:417-8.

66. Rocco G, Rendina EA, Meroni A, et al. Prognostic factors after surgical treatment of lung cancer invading the diaphragm. Ann Thorac Surg 1999;68:2065-8.

67. Inoue K, Sato M, Fujimura S, et al. Prognostic assessment of 1310 patients with non-small-cell lung cancer who underwent complete resection from 1980 to 1993 . J Thorac Cardiovasc Surg 1998;116:407-11.

68. Weksler B, Bains M, Burt M, et al. Resection of lung cancer invading the diaphragm. J Thorac Cardiovasc Surg 1997;114:500-1.

69. Ilonen I, Jones DR. Initial extended resection or neoadjuvant therapy for T4 non-small cell lung cancerwhat is the evidence? Shanghai Chest 2018;2:76.
70. Pitz CC, Brutel de la Riviere A, van Swieten HA, et al. Results of surgical treatment of T4 non-small cell lung cancer. Eur J Cardiothorac Surg 2003;24:1013-8.

71. Riquet M, Grand B, Arame A, et al. Lung cancer invading the pericardium: quantum of lymph nodes. Ann Thorac Surg 2010;90:1773-7.

72. Wu L, Xu Z, Zhao X, et al. Surgical treatment of lung cancer invading the left atrium or base of the pulmonary vein. World J Surg 2009;33:492-6.

73. Tsukioka T, Takahama M, Nakajima R, et al. Surgical outcome of patients with lung cancer involving the left atrium. Int J Clin Oncol 2016;21:1046-50.

74. Galvaing G, Tardy MM, Cassagnes L, et al. Left atrial resection for T4 lung cancer without cardiopulmonary bypass: technical aspects and outcomes. Ann Thorac Surg 2014;97:1708-13.

75. Stella F, Dell'Amore A, Caroli G, et al. Surgical results and long-term follow-up of T(4)-non-small cell lung cancer invading the left atrium or the intrapericardial base of the pulmonary veins. Interact Cardiovasc Thorac Surg 2012;14:415-9.

76. Spaggiari L, D' Aiuto M, Veronesi G, et al. Extended pneumonectomy with partial resection of the left atrium, without cardiopulmonary bypass, for lung cancer. Ann Thorac Surg 2005;79:234-40.

77. Kuehnl A, Lindner M, Hornung HM, et al. Atrial resection for lung cancer: morbidity, mortality, and longterm follow-up. World J Surg 2010;34:2233-9.

78. Fukuse T, Wada H, Hitomi S. Extended operation for non-small cell lung cancer invading great vessels and left atrium. Eur J Cardiothorac Surg 1997;11:664-9.

79. Ratto GB, Costa R, Vassallo G, et al. Twelve-year experience with left atrial resection in the treatment of non-small cell lung cancer. Ann Thorac Surg 2004;78:234-7.

80. Bobbio A, Carbognani P, Grapeggia M, et al. Surgical outcome of combined pulmonary and atrial resection for lung cancer. Thorac Cardiovasc Surg 2004;52:180-2.

81. Tsuchiya R, Asamura H, Kondo H, et al. Extended resection of the left atrium, great vessels, or both for lung cancer. Ann Thorac Surg 1994;57:960-5.

82. Osaki T, Sugio K, Hanagiri T, et al. Survival and prognostic factors of surgically resected T4 non-small cell lung cancer. Ann Thorac Surg 2003;75:1745-51; discussion 1751.

83. Muralidaran A, Detterbeck FC, Boffa DJ, et al. Long-term survival after lung resection for non-small cell lung cancer with circulatory bypass: a systematic review. J Thorac 
Cardiovasc Surg 2011;142:1137-42.

84. Langer NB, Mercier O, Fabre D, et al. Outcomes after resection of T4 non-small cell lung cancer using cardiopulmonary bypass. Ann Thorac Surg 2016;102:902-10.

85. Spaggiari L, Thomas $\mathrm{P}$, Magdeleinat $\mathrm{P}$, et al. Superior vena cava resection with prosthetic replacement for non-small cell lung cancer: long-term results of a multicentric study. Eur J Cardiothorac Surg 2002;21:1080-6.

86. Shargall Y, de Perrot M, Keshavjee S, et al. 15 years single center experience with surgical resection of the superior vena cava for non-small cell lung cancer. Lung Cancer 2004;45:357-63.

87. Suzuki K, Asamura H, Watanabe S, et al. Combined resection of superior vena cava for lung carcinoma: prognostic significance of patterns of superior vena cava invasion. Ann Thorac Surg 2004;78:1184-9; discussion 1184-9.

88. Misthos P, Papagiannakis G, Kokotsakis J, et al. Surgical management of lung cancer invading the aorta or the superior vena cava. Lung Cancer 2007;56:223-7.

89. Spaggiari L, Regnard JF, Magdeleinat P, et al. Extended resections for bronchogenic carcinoma invading the superior vena cava system. Ann Thorac Surg 2000;69:233-6.

90. Spaggiari L, Magdeleinat P, Kondo H, et al. Results of superior vena cava resection for lung cancer. Analysis of prognostic factors. Lung Cancer 2004;44:339-46.

91. Dartevelle PG, Chapelier AR, Pastorino U, et al. Longterm follow-up after prosthetic replacement of the superior vena cava combined with resection of mediastinalpulmonary malignant tumors. J Thorac Cardiovasc Surg 1991;102:259-65.

92. Leo F, Bellini R, Conti B, et al. Superior vena cava resection in thoracic malignancies: does prosthetic replacement pose a higher risk? Eur J Cardiothorac Surg 2010;37:764-9.

93. Thomas P, Magnan PE, Moulin G, et al. Extended operation for lung cancer invading the superior vena cava. Eur J Cardiothorac Surg 1994;8:177-82.

94. Sekine Y, Suzuki H, Saitoh Y, et al. Prosthetic reconstruction of the superior vena cava for malignant disease: surgical techniques and outcomes. Ann Thorac Surg 2010;90:223-8.

95. Lanuti M, De Delva PE, Gaissert HA, et al. Review of superior vena cava resection in the management of benign disease and pulmonary or mediastinal malignancies. Ann Thorac Surg 2009;88:392-7.
96. Ciccone AM, Venuta F, D'Andrilli A, et al. Long-term patency of the stapled bovine pericardial conduit for replacement of the superior vena cava. Eur J Cardiothorac Surg 2011;40:1487-91; discussion 1491.

97. Poggi C, Mantovani S, Pecoraro Y, et al. Pulmonary artery resections for lung cancer-when and how? Shanghai Chest 2018;2:79.

98. Venuta F, Ciccone AM, Anile M, et al. Reconstruction of the pulmonary artery for lung cancer: long-term results. J Thorac Cardiovasc Surg 2009;138:1185-91.

99. Marulli G, Rendina EA, Klepetko W, et al. Surgery for T4 lung cancer invading the thoracic aorta: Do we push the limits? J Surg Oncol 2017;116:1141-9.

100. Collaud S, Waddell TK, Yasufuku K, et al. Thoracic aortic endografting facilitates the resection of tumors infiltrating the aorta. J Thorac Cardiovasc Surg 2014;147:1178-82; discussion 1182 .

101. Klepetko W, Wisser W, Birsan T, et al. T4 lung tumors with infiltration of the thoracic aorta: is an operation reasonable? Ann Thorac Surg 1999;67:340-4.

102. Shiraishi T, Shirakusa T, Miyoshi T, et al. Extended resection of T4 lung cancer with invasion of the aorta: is it justified? Thorac Cardiovasc Surg 2005;53:375-9.

103. Ohta M, Hirabayasi H, Shiono H, et al. Surgical resection for lung cancer with infiltration of the thoracic aorta. J Thorac Cardiovasc Surg 2005;129:804-8.

104. Wex P, Graeter T, Zaraca F, et al. Surgical resection and survival of patients with unsuspected single node positive lung cancer (NSCLC) invading the descending aorta. Thorac Surg Sci 2009;6:Doc02.

105. Mitchell JD, Mathisen DJ, Wright CD, et al. Resection for bronchogenic carcinoma involving the carina: long-term results and effect of nodal status on outcome. J Thorac Cardiovasc Surg 2001;121:465-71.

106.de Perrot M, Fadel E, Mercier O, et al. Long-term results after carinal resection for carcinoma: does the benefit warrant the risk? J Thorac Cardiovasc Surg 2006;131:81-9.

107.Regnard JF, Perrotin C, Giovannetti R, et al. Resection for tumors with carinal involvement: technical aspects, results, and prognostic factors. Ann Thorac Surg 2005;80:1841-6.

108. Porhanov VA, Poliakov IS, Selvaschuk AP, et al. Indications and results of sleeve carinal resection. Eur J Cardiothorac Surg 2002;22:685-94.

109. Mitchell JD, Mathisen DJ, Wright CD, et al. Clinical experience with carinal resection. J Thorac Cardiovasc Surg 1999;117:39-52; discussion 52-3. 
110. Dartevelle PG, Khalife J, Chapelier A, et al. Tracheal sleeve pneumonectomy for bronchogenic carcinoma: report of 55 cases. Ann Thorac Surg 1988;46:68-72.

111. Grunenwald DH, Mazel C, Girard P, et al. Radical en bloc resection for lung cancer invading the spine. J Thorac Cardiovasc Surg 2002;123:271-9.

112.Fadel E, Missenard G, Court C, et al. Long-term outcomes of en bloc resection of non-small cell lung cancer invading the thoracic inlet and spine. Ann Thorac Surg 2011;92:1024-30; discussion 1030.

113.Koizumi K, Haraguchi S, Hirata T, et al. Surgical treatment of lung cancer with vertebral invasion. Ann Thorac Cardiovasc Surg 2004;10:229-34.

114. Collaud S, Fadel E, Schirren J, et al. En Bloc Resection of pulmonary sulcus non-small cell lung cancer invading the spine: a systematic literature review and pooled data analysis. Ann Surg 2015;262:184-8.

115. Mody GN, Bravo Iniguez C, Armstrong K, et al. Early surgical outcomes of en bloc resection requiring vertebrectomy for malignancy invading the thoracic spine. Ann Thorac Surg 2016;101:231-6; discussion 236-7.

116. Schirren J, Donges T, Melzer M, et al. En bloc resection of non-small-cell lung cancer invading the spine. Eur J Cardiothorac Surg 2011;40:647-54.

117.Anraku M, Waddell TK, de Perrot M, et al. Induction chemoradiotherapy facilitates radical resection of 'T4 non-small cell lung cancer invading the spine. J Thorac Cardiovasc Surg 2009;137:441-7.e1.

118. Bilsky MH, Vitaz TW, Boland PJ, et al. Surgical treatment of superior sulcus tumors with spinal and brachial plexus involvement. J Neurosurg 2002;97:301-9.

119. Gandhi S, Walsh GL, Komaki R, et al. A multidisciplinary surgical approach to superior sulcus tumors with vertebral invasion. Ann Thorac Surg 1999;68:1778-84; discussion 1784-5.

120. Brunelli A, Refai MA, Salati M, et al. Carbon monoxide lung diffusion capacity improves risk stratification in patients without airflow limitation: evidence for systematic measurement before lung resection. Eur J Cardiothorac Surg 2006;29:567-70.

121. Brunelli A, Charloux A, Bolliger CT, et al. ERS/ESTS clinical guidelines on fitness for radical therapy in lung cancer patients (surgery and chemo-radiotherapy). Eur Respir J 2009;34:17-41.

122. O'Rourke N, Roque IFM, Farre Bernado N, et al. Concurrent chemoradiotherapy in non-small cell lung cancer. Cochrane Database Syst Rev 2010;(6):CD002140. 123. Curran WJ Jr, Paulus R, Langer CJ, et al. Sequential vs. concurrent chemoradiation for stage III non-small cell lung cancer: randomized phase III trial RTOG 9410. J Natl Cancer Inst 2011;103:1452-60.

124.Aupérin A, Le Péchoux C, Rolland E, et al. Meta-analysis of concomitant versus sequential radiochemotherapy in locally advanced non-small-cell lung cancer. J Clin Oncol 2010;28:2181-90.

125. Socinski MA, Rosenman JG, Halle J, et al. Dose-escalating conformal thoracic radiation therapy with induction and concurrent carboplatin/paclitaxel in unresectable stage IIIA/B nonsmall cell lung carcinoma: a modified phase I/II trial. Cancer 2001;92:1213-23.

126. Furuse K, Fukuoka M, Kawahara M, et al. Phase III study of concurrent versus sequential thoracic radiotherapy in combination with mitomycin, vindesine, and cisplatin in unresectable stage III non-small-cell lung cancer. J Clin Oncol 1999;17:2692-9.

127. Fournel P, Robinet G, Thomas P, et al. Randomized phase III trial of sequential chemoradiotherapy compared with concurrent chemoradiotherapy in locally advanced non-small-cell lung cancer: Groupe Lyon-SaintEtienne d'Oncologie Thoracique-Groupe Francais de Pneumo-Cancerologie NPC 95-01 Study. J Clin Oncol 2005;23:5910-7.

128. Gewanter RM, Rosenzweig KE, Chang JY, et al. ACR Appropriateness Criteria: nonsurgical treatment for nonsmall-cell lung cancer: good performance status/definitive intent. Curr Probl Cancer 2010;34:228-49.

129. Howington JA, Blum MG, Chang AC, et al. Treatment of stage I and II non-small cell lung cancer: Diagnosis and management of lung cancer, 3rd ed: American College of Chest Physicians evidence-based clinical practice guidelines. Chest 2013;143:e278S-313S.

130. Villamizar N, Swanson SJ. Lobectomy vs. segmentectomy for NSCLC $(\mathrm{T}<2 \mathrm{~cm})$. Ann Cardiothorac Surg 2014;3:160-6.

131.Landreneau RJ, Normolle DP, Christie NA, et al. Recurrence and survival outcomes after anatomic segmentectomy versus lobectomy for clinical stage I nonsmall-cell lung cancer: a propensity-matched analysis. J Clin Oncol 2014;32:2449-55.

132. Altorki NK, Yip R, Hanaoka T, et al. Sublobar resection is equivalent to lobectomy for clinical stage 1A lung cancer in solid nodules. J Thorac Cardiovasc Surg 2014;147:75462; discussion 762-4.

133. Sienel W, Dango S, Kirschbaum A, et al. Sublobar resections in stage IA non-small cell lung cancer: segmentectomies result in significantly better cancer- 
related survival than wedge resections. Eur J Cardiothorac Surg 2008;33:728-34.

134. Sienel W, Stremmel C, Kirschbaum A, et al. Frequency of local recurrence following segmentectomy of stage IA nonsmall cell lung cancer is influenced by segment localisation and width of resection margins--implications for patient selection for segmentectomy. Eur J Cardiothorac Surg 2007;31:522-7; discussion 527-8.

135.Manser R, Wright G, Hart D, et al. Surgery for early stage non-small cell lung cancer. Cochrane Database Syst Rev 2005;(1):CD004699.

136. Darling GE, Allen MS, Decker PA, et al. Randomized trial of mediastinal lymph node sampling versus complete lymphadenectomy during pulmonary resection in the patient with N0 or N1 (less than hilar) non-small cell carcinoma: results of the American College of Surgery Oncology Group Z0030 Trial. J Thorac Cardiovasc Surg 2011;141:662-70.

137. Allen MS, Darling GE, Pechet TT, et al. Morbidity and mortality of major pulmonary resections in patients with early-stage lung cancer: initial results of the randomized, prospective ACOSOG Z0030 trial. Ann Thorac Surg 2006;81:1013-9; discussion 1019-20.

138. Donington J, Ferguson M, Mazzone P, et al. American College of Chest Physicians and Society of Thoracic Surgeons consensus statement for evaluation and management for high-risk patients with stage I non-small cell lung cancer. Chest 2012;142:1620-35.

139. Lutz ST, Jones J, Chow E. Role of radiation therapy in palliative care of the patient with cancer. J Clin Oncol 2014;32:2913-9.

140. Chang JY, Kestin LL, Barriger RB, et al. ACR Appropriateness Criteria ${ }^{\circledR}$ nonsurgical treatment for locally advanced non-small-cell lung cancer: good performance status/definitive intent. Oncology (Williston Park) 2014;28:706-10, 712, 714 passim.

141. Rosenzweig KE, Chang JY, Chetty IJ, et al. ACR appropriateness criteria nonsurgical treatment for nonsmall-cell lung cancer: poor performance status or palliative intent. J Am Coll Radiol 2013;10:654-64.

142. Sun A, Hu C, Wong SJ, et al. Prophylactic Cranial irradiation vs observation in patients with locally advanced non-small cell lung cancer: a long-term update of the NRG Oncology/RTOG 0214 phase 3 randomized clinical trial. JAMA Oncol 2019;5:847-55.

143. Gore EM, Bae K, Wong SJ, et al. Phase III comparison of prophylactic cranial irradiation versus observation in patients with locally advanced non-small-cell lung cancer: primary analysis of radiation therapy oncology group study RTOG 0214. J Clin Oncol 2011;29:272-8.

144.Putora PM, Leskow P, McDonald F, et al. International guidelines on stage III N2 nonsmall cell lung cancer: surgery or radiotherapy? ERJ Open Research 2020;6:00159-2019.

145. Robinson LA, Ruckdeschel JC, Wagner H, Jr., et al. Treatment of non-small cell lung cancer-stage IIIA: ACCP evidence-based clinical practice guidelines (2nd edition). Chest 2007;132:243S-65S.

146. Cerfolio RJ, Bryant AS, Jones VL, et al. Pulmonary resection after concurrent chemotherapy and high dose (60Gy) radiation for non-small cell lung cancer is safe and may provide increased survival. Eur J Cardiothorac Surg 2009;35:718-23; discussion 723.

147.Lorent N, De Leyn P, Lievens Y, et al. Long-term survival of surgically staged IIIA-N2 non-small-cell lung cancer treated with surgical combined modality approach: analysis of a 7-year prospective experience. Ann Oncol 2004;15:1645-53.

148. Cerfolio RJ, Maniscalco L, Bryant AS. The treatment of patients with stage IIIA non-small cell lung cancer from N2 disease: who returns to the surgical arena and who survives. Ann Thorac Surg 2008;86:912-20; discussion 912-20.

149.Pless M, Stupp R, Ris HB, et al. Induction chemoradiation in stage IIIA/N2 non-small-cell lung cancer: a phase 3 randomised trial. Lancet 2015;386:1049-56.

150. Koshy M, Fedewa SA, Malik R, et al. Improved survival associated with neoadjuvant chemoradiation in patients with clinical stage IIIA(N2) non-small-cell lung cancer. J Thorac Oncol 2013;8:915-22.

151. Thomas M, Rube C, Hoffknecht P, et al. Effect of preoperative chemoradiation in addition to preoperative chemotherapy: a randomised trial in stage III non-smallcell lung cancer. Lancet Oncol 2008;9:636-48.

152.Gopal RS, Dubey S, Rosenzweig KE, et al. ACR Appropriateness Criteria(R) on Induction and Adjuvant Therapy for Stage N2 Non-Small-Cell Lung Cancer: expert panel on radiation oncology-lung. Int J Radiat Oncol Biol Phys 2010;78:969-74.

153. Evans NR 3rd, Li S, Wright CD, et al. The impact of induction therapy on morbidity and operative mortality after resection of primary lung cancer. J Thorac Cardiovasc Surg 2010;139:991-6.e1-2.

154. Gaissert HA, Keum DY, Wright CD, et al. POINT: Operative risk of pneumonectomy--influence of preoperative induction therapy. J Thorac Cardiovasc Surg 
2009;138:289-94.

155. Mansour Z, Kochetkova EA, Ducrocq X, et al. Induction chemotherapy does not increase the operative risk of pneumonectomy! Eur J Cardiothorac Surg 2007;31:181-5.

156. Weder W, Collaud S, Eberhardt WE, et al.

Pneumonectomy is a valuable treatment option after neoadjuvant therapy for stage III non-small-cell lung cancer. J Thorac Cardiovasc Surg 2010;139:1424-30.

157.Kappers I, van Sandick JW, Burgers SA, et al. Surgery after induction chemotherapy in stage IIIA-N2 non-small cell lung cancer: why pneumonectomy should be avoided. Lung Cancer 2010;68:222-7.

158. NSCLC Meta-analysis Collaborative Group. Preoperative chemotherapy for non-small-cell lung cancer: a systematic review and meta-analysis of individual participant data. Lancet 2014;383:1561-71.

159.Pisters KM, Vallieres E, Crowley JJ, et al. Surgery with or without preoperative paclitaxel and carboplatin in earlystage non-small-cell lung cancer: Southwest Oncology Group Trial S9900, an intergroup, randomized, phase III trial. J Clin Oncol 2010;28:1843-9.

160. Roth JA, Fossella F, Komaki R, et al. A randomized trial comparing perioperative chemotherapy and surgery with surgery alone in resectable stage IIIA non-small-cell lung cancer. J Natl Cancer Inst 1994;86:673-80.

161. Gilligan D, Nicolson M, Smith I, et al. Preoperative chemotherapy in patients with resectable non-small cell lung cancer: results of the MRC LU22/NVALT 2/ EORTC 08012 multicentre randomised trial and update of systematic review. Lancet 2007;369:1929-37.

162. Burdett SS, Stewart LA, Rydzewska L. Chemotherapy and surgery versus surgery alone in non-small cell lung cancer. Cochrane Database Syst Rev 2007;(3):CD006157.

163. Rosell R, Gomez-Codina J, Camps C, et al. A randomized trial comparing preoperative chemotherapy plus surgery with surgery alone in patients with non-small-cell lung cancer. N Engl J Med 1994;330:153-8.

164. Pisters K, Vallieres E, Bunn P, et al. S9900: A phase III trial of surgery alone or surgery plus preoperative (preop) paclitaxel/carboplatin (PC) chemotherapy in early stage non-small cell lung cancer (NSCLC): Preliminary results. J Clin Oncol 2005;23:LBA7012.

165. Rusch VW, Albain KS, Crowley JJ, et al. Surgical resection of stage IIIA and stage IIIB non-small-cell lung cancer after concurrent induction chemoradiotherapy. A Southwest Oncology Group trial. J Thorac Cardiovasc Surg 1993;105:97-104; discussion 104-6.

166. Sher DJ, Fidler MJ, Liptay MJ, et al. Comparative effectiveness of neoadjuvant chemoradiotherapy versus chemotherapy alone followed by surgery for patients with stage IIIA non-small cell lung cancer. Lung Cancer 2015;88:267-74.

167. Shah AA, Berry MF, Tzao C, et al. Induction chemoradiation is not superior to induction chemotherapy alone in stage IIIA lung cancer. Ann Thorac Surg 2012;93:1807-12.

168. Higgins K, Chino JP, Marks LB, et al. Preoperative chemotherapy versus preoperative chemoradiotherapy for stage III (N2) non-small-cell lung cancer. Int J Radiat Oncol Biol Phys 2009;75:1462-7.

169. Sonett JR, Suntharalingam M, Edelman MJ, et al. Pulmonary resection after curative intent radiotherapy (>59 Gy) and concurrent chemotherapy in non-small-cell lung cancer. Ann Thorac Surg 2004;78:1200-5; discussion 1206.

170. Yang Z, Zhai C. Uniportal video-assisted thoracoscopic surgery following neoadjuvant chemotherapy for locallyadvanced lung cancer. J Cardiothorac Surg 2018;13:33.

171.Huang J, Xu X, Chen H, et al. Feasibility of complete video-assisted thoracoscopic surgery following neoadjuvant therapy for locally advanced non-small cell lung cancer. J Thorac Dis 2013;5 Suppl 3:S267-73.

172. Fan J, Yao J, Wang Q, et al. Safety and feasibility of uniportal video-assisted thoracoscopic surgery for locally advanced non-small cell lung cancer. J Thorac Dis 2016;8:3543-50.

173. Gonzalez-Rivas D, Fieira E, Delgado M, et al. Is uniportal thoracoscopic surgery a feasible approach for advanced stages of non-small cell lung cancer? J Thorac Dis 2014;6:641-8.

174. Song WA, Zhou NK, Wang W, et al. Survival benefit of neoadjuvant chemotherapy in non-small cell lung cancer: an updated meta-analysis of 13 randomized control trials. J Thorac Oncol 2010;5:510-6.

175. Scagliotti GV, Pastorino U, Vansteenkiste JF, et al. Randomized phase III study of surgery alone or surgery plus preoperative cisplatin and gemcitabine in stages IB to IIIA non-small-cell lung cancer. J Clin Oncol 2012;30:172-8.

176. Depierre A, Milleron B, Moro-Sibilot D, et al. Preoperative chemotherapy followed by surgery compared with primary surgery in resectable stage I (except T1N0), II, and IIIa non-small-cell lung cancer. J Clin Oncol 2002;20:247-53.

177. Boffa DJ, Hancock JG, Yao X, et al. Now or later: evaluating the importance of chemotherapy timing in 
resectable stage III (N2) lung cancer in the National Cancer Database. Ann Thorac Surg 2015;99:200-8.

178. Westeel V, Quoix E, Puyraveau M, et al. A randomised trial comparing preoperative to perioperative chemotherapy in early-stage non-small-cell lung cancer (IFCT 0002 trial). Eur J Cancer 2013;49:2654-64.

179. Rosell R, Gomez-Codina J, Camps C, et al. Preresectional chemotherapy in stage IIIA non-small-cell lung cancer: a 7-year assessment of a randomized controlled trial. Lung Cancer 1999;26:7-14.

180. MacLean M, Luo X, Wang S, et al. Outcomes of neoadjuvant and adjuvant chemotherapy in stage 2 and 3 non-small cell lung cancer: an analysis of the National Cancer Database. Oncotarget 2018;9:24470-9.

181. Betticher DC. Adjuvant and neoadjuvant chemotherapy in NSCLC: a paradigm shift. Lung Cancer 2005;50S2:S9-16.

182.Felip E, Rosell R, Maestre JA, et al. Preoperative chemotherapy plus surgery versus surgery plus adjuvant chemotherapy versus surgery alone in early-stage nonsmall-cell lung cancer. J Clin Oncol 2010;28:3138-45.

183. Bueno R, Richards WG, Swanson SJ, et al. Nodal stage after induction therapy for stage IIIA lung cancer determines patient survival. Ann Thorac Surg 2000;70:1826-31.

184. de Cabanyes Candela S, Detterbeck FC. A systematic review of restaging after induction therapy for stage IIIa lung cancer: prediction of pathologic stage. J Thorac Oncol 2010;5:389-98.

185. Haager B, Wiesemann S, Passlick B, et al. Prognostic value of lymph node ratio after induction therapy in stage IIIA/N2 non-small cell lung cancer: a monocentric clinical study. J Thorac Dis 2018;10:3225-31.

186. Betticher DC, Hsu Schmitz SF, Totsch M, et al. Mediastinal lymph node clearance after docetaxel-cisplatin neoadjuvant chemotherapy is prognostic of survival in patients with stage IIIA pN2 non-small-cell lung cancer: a multicenter phase II trial. J Clin Oncol 2003;21:1752-9.

187.McElnay PJ, Choong A, Jordan E, et al. Outcome of surgery versus radiotherapy after induction treatment in patients with N2 disease: systematic review and metaanalysis of randomised trials. Thorax 2015;70:764-8.

188. Mansour Z, Kochetkova EA, Santelmo N, et al. Persistent $\mathrm{N} 2$ disease after induction therapy does not jeopardize early and medium term outcomes of pneumonectomy. Ann Thorac Surg 2008;86:228-33.

189. Port JL, Korst RJ, Lee PC, et al. Surgical resection for residual N2 disease after induction chemotherapy. Ann Thorac Surg 2005;79:1686-90.
190. Ripley RT, Suzuki K, Tan KS, et al. Postinduction positron emission tomography assessment of $\mathrm{N} 2$ nodes is not associated with ypN2 disease or overall survival in stage IIIA non-small cell lung cancer. J Thorac Cardiovasc Surg 2016;151:969-77, 979.e1-3.

191. Massard G, Renaud S, Reeb J, et al. N2-IIIA nonsmall cell lung cancer: a plea for surgery! J Thorac Dis 2016;8:S849-54.

192.Zhi XY, Yu JM, Shi YK. Chinese guidelines on the diagnosis and treatment of primary lung cancer $(2015$ version). Cancer 2015;121 Suppl 17:3165-81.

193.Lim E, Baldwin D, Beckles M, et al. Guidelines on the radical management of patients with lung cancer. Thorax 2010;65 Suppl 3:iii1-27.

194. Andre F, Grunenwald D, Pignon JP, et al. Survival of patients with resected N2 non-small-cell lung cancer: evidence for a subclassification and implications. J Clin Oncol 2000;18:2981-9.

195. Bradbury P, Sivajohanathan D, Chan A, et al. Postoperative adjuvant systemic therapy in completely resected nonsmall-cell lung cancer: a systematic review. Clin Lung Cancer 2017;18:259-73.e8.

196. Arriagada R, Bergman B, Dunant A, et al. Cisplatinbased adjuvant chemotherapy in patients with completely resected non-small-cell lung cancer. N Engl J Med 2004;350:351-60.

197. Winton T, Livingston R, Johnson D, et al. Vinorelbine plus cisplatin vs. observation in resected non-small-cell lung cancer. N Engl J Med 2005;352:2589-97.

198. Douillard JY, Rosell R, De Lena M, et al. Adjuvant vinorelbine plus cisplatin versus observation in patients with completely resected stage IB-IIIA non-small-cell lung cancer (Adjuvant Navelbine International Trialist Association [ANITA]): a randomised controlled trial. Lancet Oncol 2006;7:719-27.

199.Burdett S, Pignon JP, Tierney J, et al. Adjuvant chemotherapy for resected early-stage non-small cell lung cancer. Cochrane Database Syst Rev 2015;(3):CD011430.

200.Arriagada R, Dunant A, Pignon JP, et al. Long-term results of the international adjuvant lung cancer trial evaluating adjuvant Cisplatin-based chemotherapy in resected lung cancer. J Clin Oncol 2010;28:35-42.

201. Butts CA, Ding K, Seymour L, et al. Randomized phase III trial of vinorelbine plus cisplatin compared with observation in completely resected stage IB and II nonsmall-cell lung cancer: updated survival analysis of JBR-10. J Clin Oncol 2010;28:29-34. 
202. Douillard JY, Tribodet H, Aubert D, et al. Adjuvant cisplatin and vinorelbine for completely resected non-small cell lung cancer: subgroup analysis of the Lung Adjuvant Cisplatin Evaluation. J Thorac Oncol 2010;5:220-8.

203. Pignon JP, Tribodet H, Scagliotti GV, et al. Lung adjuvant cisplatin evaluation: a pooled analysis by the LACE Collaborative Group. J Clin Oncol 2008;26:3552-9.

204. Wisnivesky JP, Smith CB, Packer S, et al. Survival and risk of adverse events in older patients receiving postoperative adjuvant chemotherapy for resected stages II-IIIA lung cancer: observational cohort study. BMJ 2011;343:d4013.

205.Pallis AG, Gridelli C, Wedding U, et al. Management of elderly patients with NSCLC; updated expert's opinion paper: EORTC Elderly Task Force, Lung Cancer Group and International Society for Geriatric Oncology. Ann Oncol 2014;25:1270-83.

206. Burdett S, Rydzewska L, Tierney J, et al. Postoperative radiotherapy for non-small cell lung cancer. Cochrane Database Syst Rev 2016;10:CD002142.

207.Postoperative radiotherapy in non-small-cell lung cancer: systematic review and meta-analysis of individual patient data from nine randomised controlled trials. PORT Metaanalysis Trialists Group. Lancet 1998;352:257-63.

208.PORT Meta-analysis Trialists Group. Postoperative radiotherapy for non-small cell lung cancer. Cochrane Database Syst Rev 2005;(2):CD002142.

209. Burdett S, Stewart L, Group PM-a. Postoperative radiotherapy in non-small-cell lung cancer: update of an individual patient data meta-analysis. Lung Cancer 2005;47:81-3.

210. Lally BE, Zelterman D, Colasanto JM, et al. Postoperative radiotherapy for stage II or III non-small-cell lung cancer using the surveillance, epidemiology, and end results database. J Clin Oncol 2006;24:2998-3006.

211.Le Péchoux C, Dunant A, Pignon JP, et al. Need for a new trial to evaluate adjuvant postoperative radiotherapy in non-small-cell lung cancer patients with N2 mediastinal involvement. J Clin Oncol 2007;25:e10-1.

212.Francis S, Orton A, Stoddard G, et al. Sequencing of postoperative radiotherapy and chemotherapy for locally advanced or incompletely resected non-small-cell lung cancer. J Clin Oncol 2018;36:333-41.

213. Wang EH, Corso CD, Rutter CE, et al. Postoperative radiation therapy is associated with improved overall survival in incompletely resected stage II and III nonsmall-cell lung cancer. J Clin Oncol 2015;33:2727-34. 214.Hancock JG, Rosen JE, Antonicelli A, et al. Impact of adjuvant treatment for microscopic residual disease after non-small cell lung cancer surgery. Ann Thorac Surg 2015;99:406-13.

215.Edwards JG, Chansky K, Van Schil P, et al. The IASLC Lung Cancer Staging Project: analysis of resection margin status and proposals for residual tumor descriptors for non-small cell lung cancer. J Thorac Oncol 2020;15:344-59.

216. Rusch VW. Management of Pancoast tumours. Lancet Oncol 2006;7:997-1005.

217. Narayan S, Thomas CR Jr. Multimodality therapy for Pancoast tumor. Nat Clin Pract Oncol 2006;3:484-91.

218. Rusch VW, Parekh KR, Leon L, et al. Factors determining outcome after surgical resection of T3 and T4 lung cancers of the superior sulcus. J Thorac Cardiovasc Surg 2000;119:1147-53.

219. Wen J, Liu D, Chen D, et al. Treatment of clinical T4 stage superior sulcus non-small cell lung cancer: a propensity-matched analysis of the surveillance, epidemiology, and end results database. Biosci Rep 2019;39:BSR20181545.

220.Xue Z, Wu F, Pierson KE, et al. Survival in surgical and nonsurgical patients with superior sulcus tumors. Ann Thorac Surg 2017;104:988-97.

221.De Leyn P, Vansteenkiste J, Lievens Y, et al. Survival after trimodality treatment for superior sulcus and central T4 non-small cell lung cancer. J Thorac Oncol 2009;4:62-8.

222. DiPerna CA, Wood DE. Surgical management of T3 and T4 lung cancer. Clin Cancer Res 2005;11:5038s-44s.

223. Yang HX, Hou X, Lin P, et al. Survival and risk factors of surgically treated mediastinal invasion T4 non-small cell lung cancer. Ann Thorac Surg 2009;88:372-8.

224. Nakagawa T, Okumura N, Miyoshi K, et al. Prognostic factors in patients with ipsilateral pulmonary metastasis from non-small cell lung cancer. Eur J Cardiothorac Surg 2005;28:635-9.

225. Salazar MC, Rosen JE, Arnold BN, et al. Adjuvant Chemotherapy for T3 Non-Small Cell Lung Cancer with Additional Tumor Nodules in the Same Lobe. J Thorac Oncol 2016;11:1090-100.

226. Lee JG, Lee CY, Kim DJ, et al. Non-small cell lung cancer with ipsilateral pulmonary metastases: prognosis analysis and staging assessment. Eur J Cardiothorac Surg 2008;33:480-4.

227. Nagai K, Sohara Y, Tsuchiya R, et al. Prognosis of resected non-small cell lung cancer patients with intrapulmonary metastases. J Thorac Oncol 2007;2:282-6. 
228. Port JL, Korst RJ, Lee PC, et al. Surgical resection for multifocal (T4) non-small cell lung cancer: is the T4 designation valid? Ann Thorac Surg 2007;83:397-400.

229. Shaw JP, Dembitzer FR, Wisnivesky JP, et al. Videoassisted thoracoscopic lobectomy: state of the art and future directions. Ann Thorac Surg 2008;85:S705-9.

230.Cheng D, Downey RJ, Kernstine K, et al. Video-assisted thoracic surgery in lung cancer resection: a meta-analysis and systematic review of controlled trials. Innovations (Phila) 2007;2:261-92.

231. Whitson BA, Andrade RS, Boettcher A, et al. Videoassisted thoracoscopic surgery is more favorable than thoracotomy for resection of clinical stage I non-small cell lung cancer. Ann Thorac Surg 2007;83:1965-70.

232. Whitson BA, Groth SS, Duval SJ, et al. Surgery for earlystage non-small cell lung cancer: a systematic review of the video-assisted thoracoscopic surgery versus thoracotomy approaches to lobectomy. Ann Thorac Surg 2008;86:200816; discussion 2016-8.

233. Scott WJ, Allen MS, Darling G, et al. Video-assisted thoracic surgery versus open lobectomy for lung cancer: a secondary analysis of data from the American College of Surgeons Oncology Group Z0030 randomized clinical trial. J Thorac Cardiovasc Surg 2010;139:976-81; discussion 981-3.

234. Atkins BZ, Harpole DH Jr, Mangum JH, et al. Pulmonary segmentectomy by thoracotomy or thoracoscopy: reduced hospital length of stay with a minimally-invasive approach. Ann Thorac Surg 2007;84:1107-12; discussion 1112-3.

235. Swanson SJ, Herndon JE 2nd, D'Amico TA, et al. Videoassisted thoracic surgery lobectomy: report of CALGB 39802--a prospective, multi-institution feasibility study. J Clin Oncol 2007;25:4993-7.

236. Ohtsuka T, Nomori H, Horio H, et al. Is major pulmonary resection by video-assisted thoracic surgery an adequate procedure in clinical stage I lung cancer? Chest 2004;125:1742-6.

237. McKenna RJ Jr. New approaches to the minimally invasive treatment of lung cancer. Cancer J 2005;11:73-6.

238. Demmy TL, Nwogu C. Is video-assisted thoracic surgery lobectomy better? Quality of life considerations. Ann Thorac Surg 2008;85:S719-28.

239. Cattaneo SM, Park BJ, Wilton AS, et al. Use of videoassisted thoracic surgery for lobectomy in the elderly results in fewer complications. Ann Thorac Surg 2008;85:231-5; discussion 235-6.

240.Cao C, Manganas C, Ang SC, et al. Video-assisted thoracic surgery versus open thoracotomy for non-small cell lung cancer: a meta-analysis of propensity score-matched patients. Interact Cardiovasc Thorac Surg 2013;16:244-9.

241. Ilonen IK, Rasanen JV, Knuuttila A, et al. Anatomic thoracoscopic lung resection for non-small cell lung cancer in stage $\mathrm{I}$ is associated with less morbidity and shorter hospitalization than thoracotomy. Acta Oncol 2011;50:1126-32.

242. Villamizar NR, Darrabie MD, Burfeind WR, et al. Thoracoscopic lobectomy is associated with lower morbidity compared with thoracotomy. J Thorac Cardiovasc Surg 2009;138:419-25.

243. Paul S, Altorki NK, Sheng S, et al. Thoracoscopic lobectomy is associated with lower morbidity than open lobectomy: a propensity-matched analysis from the STS database. J Thorac Cardiovasc Surg 2010;139:366-78.

244.Nicastri DG, Wisnivesky JP, Litle VR, et al. Thoracoscopic lobectomy: report on safety, discharge independence, pain, and chemotherapy tolerance. J Thorac Cardiovasc Surg 2008;135:642-7.

245. Yan TD, Black D, Bannon PG, et al. Systematic review and meta-analysis of randomized and nonrandomized trials on safety and efficacy of video-assisted thoracic surgery lobectomy for early-stage non-small-cell lung cancer. J Clin Oncol 2009;27:2553-62.

246. Cao C, Manganas C, Ang SC, et al. A meta-analysis of unmatched and matched patients comparing videoassisted thoracoscopic lobectomy and conventional open lobectomy. Ann Cardiothorac Surg 2012;1:16-23.

247.Petersen RP, Pham D, Burfeind WR, et al. Thoracoscopic lobectomy facilitates the delivery of chemotherapy after resection for lung cancer. Ann Thorac Surg 2007;83:12459; discussion 1250 .

248. Nakamura H. Systematic review of published studies on safety and efficacy of thoracoscopic and robot-assisted lobectomy for lung cancer. Ann Thorac Cardiovasc Surg 2014;20:93-8.

249. Swanson SJ, Miller DL, McKenna RJ Jr, et al. Comparing robot-assisted thoracic surgical lobectomy with conventional video-assisted thoracic surgical lobectomy and wedge resection: results from a multihospital database (Premier). J Thorac Cardiovasc Surg 2014;147:929-37.

250. Hanna JM, Berry MF, D'Amico TA. Contraindications of video-assisted thoracoscopic surgical lobectomy and determinants of conversion to open. J Thorac Dis 2013;5 Suppl 3:S182-9.

251.Fang L, Wang L, Wang Y, et al. Video assisted thoracic surgery vs. thoracotomy for locally advanced lung squamous cell carcinoma after neoadjuvant chemotherapy. 
J Cardiothorac Surg 2018;13:128.

252. Kojima K, Yoon H, Sakamoto T, et al. Adenocarcinoma with fetal features invading the right superior sulcus treated with neoadjuvant chemoradiotherapy followed by complete video-assisted thoracoscopic right upper lobectomy: a case report. Surg Case Rep 2019;5:165. 253.Park JS, Kim HK, Choi YS, et al. Unplanned conversion to thoracotomy during video-assisted thoracic surgery lobectomy does not compromise the surgical outcome. World J Surg 2011;35:590-5.

254. Villamizar NR, Darrabie M, Hanna J, et al. Impact of $\mathrm{T}$ status and $\mathrm{N}$ status on perioperative outcomes after thoracoscopic lobectomy for lung cancer. J Thorac Cardiovasc Surg 2013;145:514-20; discussion 520-1.

doi: $10.21037 /$ ccts-20-97

Cite this article as: Flury DV, Minervini F, Kocher GJ. Heterogeneity of stage IIIA non-small cell lung cancerdifferent tumours, different nodal status, different treatment, different prognosis: a narrative review. Curr Chall Thorac Surg 2022;4:13. 